\title{
Are conservative approaches to new product selling a blessing in disguise?
}

\author{
Michel van der Borgh $^{1}$ • Jeroen Schepers ${ }^{1}$
}

Received: 12 November 2015 / Accepted: 26 January 2017 /Published online: 6 April 2017

(C) The Author(s) 2017. This article is published with open access at Springerlink.com

\begin{abstract}
A new product's success in the marketplace largely depends on salesforce actions. Many B2B salespeople display conservatism when confronted with new products in their portfolio, such that they maximize their efforts to sell existing products before engaging in efforts to sell the new product. So far, it is unclear whether this conservative selling behavior (CSB) is harmful to new product selling performance, and how this behavior can be managed. Building on perceived risk processing theory, and employing multi-level structural equation modeling on a multi-source dataset, the authors empirically substantiate that salespeople's CSB makes their effort to sell new products more effective. Remarkably, such effort is then valued less by sales managers. The authors also find that CSB is a result of a risk assessment and evaluation process, in which internal marketing efforts (i.e., providing salespeople with information on the new product) determine the weight of perceived performance risk (i.e., new product radicalness), social risk (i.e., managerial new product orientation), and financial risk (i.e., long-term rewards). Managers looking to control the levels of CSB in their salesforce should carefully align their information support activities with the perceived risk dimensions of the new product selling situation.
\end{abstract}

John Hulland served as Area Editor for this article.

Michel van der Borgh

w.v.d.borgh@tue.nl

Jeroen Schepers

J.J.L.Schepers@tue.nl

1 Department of Industrial Engineering \& Innovation Sciences, Eindhoven University of Technology, P.O. Box 513, 5600 MB Eindhoven, The Netherlands
Keywords Sales management $\cdot$ Salesperson performance . New products $\cdot$ Conservative selling behavior .

Business-to-business $\cdot$ Perceived risk processing theory

Many business-to-business firms use their existing salesforce to sell new products. Given the increasingly rapid introduction of next generation products, salespeople face a complex product portfolio in which new products compete with proven sellers (Moore 2006). This requires salespeople to constantly make choices on whether to sell a well-established product or one that is new to the market and the salesperson, and thus bears some risk and outcome uncertainty.

Managers generally attribute the lack of product success40 to $90 \%$ of all new products fail in the marketplace - to salespeople's choices for proven sellers, rather than trying to sell new products (Ahearne et al. 2010; Wieseke et al. 2008). Companies thus invest millions of dollars annually to make new products look more attractive to salespeople ( $\mathrm{Fu}$ et al. 2010). Particularly, they try to alter a salesperson's risk perceptions by providing information that makes the benefits of the new product more salient and accessible in the individual's decision process. Unfortunately, this strategy seems unsuccessful. Only $11 \%$ of B2B salespeople see product information as an enabler of closing profitable deals (Corporate Visions 2015), and $85 \%$ to $90 \%$ of product training has no lasting impact, which amounts to $\$ 4.25$ billion of unproductive training in the U.S. alone (Stein 2011). Research by Accenture thus concludes that companies "have been investing in programs that yield little value" (Angelos et al. 2017, p. 6).

Although managers consider the risk-averse stance of salespeople toward new products to be dysfunctional (Atuahene-Gima 1997), salesperson conservatism may not be bad at all (Rackham 1998). Presenting customers with a 
proven seller before trying to sell the new product may help the salesperson accentuate the benefits of the latter because customers evaluate innovations vis-à-vis market-conform product functionality and performance. In fact, some firms have found that a careful exposure of customers to a new product increases sales effectiveness compared to an approach where customers hear all of the new product's benefits but lack a point of reference. For instance, when Sonoco, a U.S.based international packaging supplier, launched an innovative packaging, its salesforce first explained existing packaging to customers to provide them with a reference price. They then promoted the new packaging, which had the same price but an increased efficiency and a more distinctive look. This conservative approach proved very effective (Anderson et al. 2006). Thus if salespeople's conservatism is not as harmful as managers think, firms' investments to push salespeople toward selling new products may be an unnecessary resource drain or even counterproductive.

While the conservatism of salespeople stands virtually unexplored, there is clearly a strong need to know how it relates to sales performance and what factors stimulate or discourage salespeople's conservatism. In response we introduce the concept of conservative selling behavior (CSB) and build on perceived risk processing theory (Conchar et al. 2004; Jacoby and Kaplan 1972) to investigate its antecedents and consequences. Because the process of dealing with perceived risk is inextricably linked with information processing (e.g., Conchar et al. 2004; Dowling and Staelin 1994), we pay particular attention to the role of new product information provided to salespeople. We empirically substantiate that managers do not appreciate salespeople's conservatism, despite the fact that it proves to be an effective strategy to sell new products. We then provide clear insights into how sales managers may control CSB. More specifically, we make at least three substantive contributions to existing literature.

First, by introducing CSB we extend research on salesperson behavior in the new product selling domain. More specifically, we define CSB as the extent to which a salesperson maximizes selling efforts for existing products before engaging in efforts to sell the new product. CSB does not imply rejection of the new product; the salesperson may appreciate the new offer and put in much effort to sell it (i.e., display a high persistence or intensity), but only after the options to sell existing products have been explored. This also sets CSB apart from dysfunctional selling behavior (Atuahene-Gima 1997), or new product resistance or rejection (Kauppila et al. 2010). We contrast CSB with these behaviors and show that CSB interacts with effort to positively affect new product selling performance.

Second, we add to literature on internal marketing of new products toward salespeople. We define new product information as the extent to which salespeople within a unit are collectively provided with timely, relevant, and accurate information on how the new product addresses customer needs. While Atuahene-Gima (1997) proposed that providing information to the salesforce enhances new product selling effort, Anderson and Robertson (1995) and Hughes (2013) were unable to substantiate such effects. To resolve this ambiguity, we conceptualize new product information as a contingency factor and argue for its effects through the logic of priming (Mandel 2003; Scheufele and Tewksbury 2007). Priming is providing an employee with a cue that activates particular associations in memory prior to executing a sales task. We posit that priming salespeople with new product information alters the weights of the perceived risks in salespeople's behavioral decisions under uncertainty. We find that organizations can only effectively control the level of their salespeople's CSB if they align the level of information provision with the different dimensions of perceived risk in a new product selling situation.

Finally, we bridge new product selling literature and personnel evaluation studies in the human resource domain. The majority of new product selling studies consider sales performance as the number of products sold (e.g., Fu et al. 2009; Hultink and Atuahene-Gima 2000). However, less objective elements such as the level of effort a manager perceives from a salesperson also play an important role in promotion decisions (Harris et al. 2014). We consider an objective measure of new product selling performance as well as the managerial evaluation of a salesperson's performance and show that CSB makes the effort to sell new products a stronger driver of objective performance, but a weaker driver of the managerial overall evaluation of the salesperson.

We build and test a conceptual model by employing a multi-step approach, drawing on multiple data sources. First, we conducted exploratory research with 32 employees from 15 high-tech companies to ground our hypothesized relationships and to help develop CSB's operationalization. Second, we tested the CSB scale using survey data from 172 salespeople (Sample 1) working for a global ICT company. Third, we confirmed the psychometric properties of CSB relative to related concepts using data from 191 salespeople (Sample 2) of a commercially available panel of B2B salespeople. Fourth, we tested our hypotheses using survey data from Sample 1. Fifth, we demonstrated the suitability of Sample 1 and the generalizability of our findings through descriptive meta-analytic triangulation. Finally, we augmented the data from Sample 1 with secondary market data to demonstrate the robustness of our findings across different market contexts and conditions.

Next, we describe our conceptual framework and model. 


\section{Theoretical background}

\section{Theoretical foundations of conservative selling behavior}

Central to our study is the concept of conservatism, which finds its roots in the Greek word conservare, meaning "to keep," "to preserve," or "to retain." Psychology, sociology, economics, and political science research presents conservatism in various ways, including as an individual behavior, a personality trait, an attitude, a business strategy, or a social/cultural norm (Jost et al. 2003; Wilson 2013). Individuals' conservatism associates with avoidance of cognitive complexity, a lower willingness to deviate from social convention, and a desire for stable beliefs as opposed to uncertainty (Jost et al. 2003).

We focus on conservative behavior, which entails conducting known courses of action before engaging in new and unknown activities when making decisions under risk. A useful lens for studying such behavior is provided by literature on perceived risk processing, which describes how individuals perceive risk and consequently make behavioral decisions (Conchar et al. 2004). Risk reflects the extent to which there is uncertainty about realizing potentially significant and/or disappointing outcomes of decisions.

An important assumption in perceived risk processing literature is that human decision makers are risk averse. The more outcome uncertainty surrounding a behavioral choice, the more likely individuals prefer less uncertain options. Although most sales studies also assume salespersons to be risk averse, risk aversion is seldom operationalized. We provide a more detailed and practical perspective.

\section{CSB and related concepts}

CSB represents a sales domain-specific behavioral representation of risk aversion and is defined as the extent to which a salesperson maximizes selling efforts for existing products before engaging in efforts to sell the new product. CSB describes the order in which salespeople sell products from their portfolio. Rather than making a one-time choice in selling an existing or a new product, salespeople may change their product preference (and accompanying pitch) along the sales process. CSB may even act as a deliberate strategy to reduce customer objections.

CSB shares conceptual territory with related concepts; Table 1 provides a comprehensive overview. Extant research on salesperson behavior during the sale of new products mainly focuses on effort or its variations. For instance, selling (or working) hard reflects the amount of time spent in trying to achieve sales goals (Rapp et al. 2006). New product adoption is an interaction of selling effort and commitment to the new product (Kuester et al. 2016). New product selling intentions precede effortful behavior and capture a salesperson's willingness to try hard in selling new products $(\mathrm{Fu}$ et al. 2010). CSB differs from these concepts in that it specifically accounts for the temporal ordering of selling new and existing products. Salespeople may invest much effort in selling the new product, but only after they have explored the options to sell the existing product. CSB also accounts for the fact that salespeople do not need to be positive or negative about the new product. This is an implicit premise of studies on effortrelated concepts though.

Adaptive (or smart) selling is another related concept. This reflects a salesperson's capacity to plan and execute a wide range of selling behaviors and activities based on situational considerations (Sujan et al. 1994). Unfortunately, most studies on adaptive selling consider the skill of adaptation but do not focus on specific alterations in selling behaviors or activities. CSB specifically suggests that the order of new and existing product selling may be such an adaptation.

Finally, two concepts in the new product selling literature specifically account for the trade-offs or complementarities between new and existing product selling. First, product selling ambidexterity holds that selling new and existing products can be balanced over time through alteration of activities (Van der Borgh et al. 2015). Studies on ambidexterity do not discuss the order of selling that leads to this balance. Because salespeople have to decide in each encounter which product to present to customers first, CSB provides a more informative lens on salespeople's trade-offs than product selling ambidexterity. Second, cross- and up-selling behaviors reflect selling additional items to customers who have previously purchased one or more item(s) (Kamakura 2008). Such sales behaviors are usually successful because salespeople have a foot-in-the-door with these customers. CSB may influence sales outcomes through similar principles but does not require a history of purchase to take effect.

Later, we continue to distinguish CSB from these concepts in our empirical analysis. Next, we build our conceptual model.

\section{Conceptual development}

\section{Perceived risk processing theory}

We build on perceived risk processing theory to derive CSB's antecedents. The theory posits that individuals go through three phases when they have to make product choices that involve risk: risk assessment, risk framing, and risk evaluation. In the first phase individuals perceive five dimensions of risk that ultimately influence their product choice: performance risk (i.e., chance that product does not produce desired 
Table 1 Concepts related to conservative selling behavior

Definition "The amount of time, activity or persistence of the salesperson in selling the focal new product" (Atuahene-Gima and Micheal 1998, p. 906)

\begin{tabular}{|c|c|}
\hline $\begin{array}{l}\text { Antecedents } \\
\text { (selected } \\
\text { studies) }\end{array}$ & $\begin{array}{l}\text { Salesperson's perception of the new } \\
\text { product (Ahearne et al. 2010); } \\
\text { Assigned goals, self-set goals, } \\
\text { self-efficacy (Fu et al. 2009); } \\
\text { Salesperson motivation and } \\
\text { ability (Johnson and Sohi 2016) }\end{array}$ \\
\hline $\begin{array}{l}\text { Outcomes } \\
\text { (selected } \\
\text { studies) }\end{array}$ & $\begin{array}{l}\text { Customer's perception of the new } \\
\text { product (Ahearne et al. 2010); } \\
\text { Satisfaction in selling new product, } \\
\text { performance in selling new product } \\
\text { (Atuahene-Gima and Micheal 1998); } \\
\text { New product sales (Fu et al. 2009); } \\
\text { Implementation success } \\
\text { (of new product selling strategy) } \\
\text { (Johnson and Sohi 2016) }\end{array}$ \\
\hline \multirow[t]{2}{*}{$\begin{array}{l}\text { How it } \\
\text { differs } \\
\text { from CSB }\end{array}$} & $\begin{array}{l}\text { Effort does not consider the order of } \\
\text { selling new and existing products } \\
\text { during and across sales encounters. } \\
\text { Although salespeople may invest a } \\
\text { lot of effort to sell new products, the } \\
\text { may do that only after they have } \\
\text { explored the options to sell existing } \\
\text { products, i.e., after displaying CSB. }\end{array}$ \\
\hline & New product selling intentions \\
\hline Definition & $\begin{array}{l}\text { "[I]ntentions serve as an indicator of } \\
\text { how hard people are willing to try } \\
\text { and how much effort they are } \\
\text { willing to exert over time to } \\
\text { perform a specific behavior (Ajzen } \\
\text { 1991)" (Fu et al. 2010, p. 64) }\end{array}$ \\
\hline
\end{tabular}

Antecedents Self-efficacy, attitude toward selling (selected the new product, subjective norms studies) (Fu et al. 2010); Product innovativeness, customer newness (Fu et al. 2008)

\footnotetext{
Outcomes Growth rate of new product sales (selected (Fu et al. 2010); New product studies) performance (Fu et al. 2008)
}

\section{New product adoption \\ "The interaction between the degree to which [salespeople] accept and internalize the goals of a new product (i.e., commitment) and the extent to which they work smart and hard (i.e., effort) to achieve these goals"(Atuahene-Gima 1997, p. 500)}

Expected customer demand, sales manager adoption (brand adoption; Wieseke et al. 2008); Salesforce integration (Kuester et al. 2016)

Selling performance (Hultink and Atuahene-Gima 2000);

New product success

(Kuester et al. 2016)

Adoption combines an attitude and a behavioral construct, thereby assuming that a salesperson both needs to accept the new product and put effort in its sales processes to be successful in selling the product. CSB does not require a positive attitude toward the new product. Adoption also disregards the aspect of timing, i.e., when to exert effort? CSB covers this aspect.

\section{Product selling ambidexterity}

"Salesperson ambidextrous selling behaviour as consisting of two separate constructs [selling new and selling existing products] that probably trade off $[\ldots]$ and $[\ldots]$ pursued alternately (i.e. through temporal separation)"

(Van der Borgh et al. 2015)

Manager orientation, organizational identification (Van der Borgh et al. 2015); locomotion orientation (sales-service ambidexterity; Jasmand et al. 2012); expected hunting success, acquisition-based compensation plan, prevention focus, promotion focus (huntingfarming ambidexterity; DeCarlo and Lam 2016)

Selling performance (Van der Borgh et al. 2015); Customer satisfaction, sales performance, efficiency (Jasmand et al. 2012); profit margins (DeCarlo and Lam 2016)

\section{Adaptive / Smart selling}

"Engaging in planning to determine the suitability of sales behaviors and activities that will be undertaken, the capacity to engage in a wide range of selling behaviors and activities, and the alteration of sales behaviors and activities in keeping with situational considerations" (Sujan et al. 1994, p. 40)

Experience, knowledge, empowering leader behaviors (Rapp et al. 2006)

Customer service, performance (Rapp et al. 2006)

Smart and adaptive selling suggest that the degree to which salespeople alter their sales presentation to the nature of the sales situation increases overall sales performance, but these concepts do not show how salespeople (should) adapt their presentation. CSB specifically suggests that the order of new and existing product selling may be such an adaptation.

\section{Cross- and up-selling}

Cross-selling is "sales of additional items related (or sometimes unrelated) to a previously purchased item, while up-selling involves the increase of order volume either by the sales of more units of the same purchased item, or the upgrading into a more expensive version of the purchased item" (Kamakura 2008, p. 42)

Cross-selling motivation (Schmitz 2013)

Cross-selling performance

(Schmitz 2013; Schmitz et al. 2014) 
Table 1 (continued)

How it Intention is a psychological state that differs from indicates that a salesperson is willing CSB to sell the new product. However, it does not necessarily translate into actual behavior. In addition, intentions may capture a willingness to try and exert effort over time to perform a specific behavior (Ajzen 1991), but it does not capture the temporal ordering of (selling) activities. CSB does.
Salesperson product-selling ambidexterity and CSB are related but different concepts. While both reflect situations in which new and existing products are sold, product selling ambidexterity focuses on the degree of balancing both types of products in selling activities, while CSB focuses on the order of presentation. CSB is thus a more fine-grained perspective on product selling ambidexterity.
Cross- and up-selling literature holds that the successive sale of an additional product after an initial successful sale is easier because of an increased commitment through a foot-in-the-door with the customer. CSB's effect on sales performance partially relies on the same logic but CSB does not require a past sale to be effective. outcomes), social risk (i.e., chance that product affects the way others think of individual), financial risk (i.e., chance that product involves losing money), psychological risk (i.e., chance that product does not fit well with self-concept), and physical risk (i.e., chance that product causes health injury) (Jacoby and Kaplan 1972; Mitchell 1999). In contrast to the first three risk dimensions, psychological risk and physical risk may be salient for some products (e.g., popular brands, luxury goods, food or health products), but are absent for most other products (Labrecque et al. 2016).

In the risk framing phase, individuals "sort and filter informational cues that will enable them to handle or reduce perceived risk" (Conchar et al. 2004, p. 427). Such information processing determines the relative importance of each risk dimension in an individual's choice process. Mass media, managers, friends, or researchers may (de)emphasize one or more risk dimensions in individuals' decisions through activating particular connections or associations in their cognitions - a process called priming. For instance, Mandel (2003) shows that instructing individuals to think about family and friends makes social risk more salient than financial risk in behavioral decisions.

In the last phase, risk evaluation, individuals decide on whether to make a risky choice or not. Individuals "manage the consequences of perceived risk through a process of mental accounting [...] that constitutes perceived-risk evaluation" (Conchar et al. 2004, p. 431). In general, the larger the perceived risk, the larger the threat to extant wealth and the less likely individuals make the risky choice. However, individuals also weigh the risk dimensions as potential losses against evaluation standards, specifically their initial asset levels (e.g., past investments) and trait-based personality characteristics such as self-confidence (Mitchell 1999; Wiseman and Gomez-Mejia 1998).

\section{Perceived risks in new product selling}

Although perceived risk processing theory originates in consumer research, several works extend the theory to an organizational context and outline managerially-relevant factors that make up individual's perceived risk dimensions in organizational settings (e.g., Sitkin and Pablo 1992; Wiseman and Gomez-Mejia 1998). We build on these studies to define the elements in the perceived risk processing framework and employ a qualitative study to ground our concepts and hypothesized relationships. Specifically, we interviewed 32 employees from 15 high-tech companies. ${ }^{1}$ All employees had a role in new product development and launch within their respective companies. Functions included salespeople and their managers, R\&D managers, product engineers, and marketers.

We first consider the perceived risk dimensions that salespeople rely on during risk assessment: performance, social, and financial risks. In our study context, psychological and physical risk dimensions are less of a concern because the newly introduced products do not pose risk to a salesperson's health or self-identity (cf. Labrecque et al. 2016).

A salesperson's uncertainty to what extent effort spent in the sales process will result in closing deals is largely a function of the (un)familiarity of the product to the decision maker and other stakeholders (Sitkin and Pablo 1992). One of the fundamental challenges in new product selling is new product radicalness: the extent to which the new product is perceived to be inconsistent with the systems, needs, and norms already adopted by the business customer (Micheal et al. 2003). As an R\&D manager from an automotive company said: "Our salespeople are really good in selling simple vehicles [...] But when they have to explain an innovative vehicle with four independent axes and all configurational options, the pitch becomes more complex because the customer does not understand the product." New product radicalness directly affects the chance that a salesperson can attain the desired performance outcomes and thus embodies the performance risk a salesperson perceives.

In addition, managers model risk behavior and lend their personal legitimacy to the taking or avoiding of risks

\footnotetext{
${ }^{1}$ More information about the design and descriptives of the qualitative study is available from the first author upon request.
} 
of their subordinates (Sitkin and Pablo 1992) through their selling orientations. A sales manager from an original equipment manufacturer indicated: "In contrast to more transactional selling situations where sales priorities are communicated company-wide, our complex B2B selling environment requires that I assume an important role in guiding salespeople on how to proceed with the selling task." We thus focus on managerial new product orientation, which reflects to what extent salespeople perceive managerial practices, actions, and directives that guide employees' attention, time, and effort toward the sale of new products in the firm's product portfolio.

Employees align their behavior with leader orientations to minimize potential risks while maximizing benefits with respect to pay, promotions, and job assignments (e.g., Detert and Burris 2007). Not surprisingly, a salesperson who acts in line with managerial preferences generally is evaluated favorably by his/her manager (Podsakoff and Mackenzie 1994). In contrast, a salesperson who does not follow the dominant selling orientation generally is evaluated critically by his/her manager. The stronger a manager's new product selling orientation, the more clearly employees perceive a strategic prioritization of selling goals, and the more convinced they become that deviating from working toward these goals changes the way their manager thinks about and evaluates them. We thus see managerial new product orientation as the key indicator of social risk.

Organizations also channel employees' risk assessments through monitoring and rewards (Sitkin and Pablo 1992). In B2B settings managers typically find themselves unable to set specific rewards for new products because they cannot make an accurate estimation of the true customer demand for new offerings (Schöttner 2016). Moreover, installing new product-specific incentives increases the chance that salespeople push new products that customers do not need or want. Rather than linking salary and bonuses to new product sales volume, firms typically install long-term reward systems, as put by an R\&D manager from a logistics company: "We motivate our salespeople to take a long-term perspective that aligns with our strategic objectives." Long-term rewards lower the perceived financial risks associated with selling new products because they provide more leeway for salespeople to obtain their targets (Wei and Atuahene-Gima 2009). We thus regard long-term rewards as the key indicator of perceived financial risk and define them as incentives that aim to facilitate the achievement of various long-term objectives and specified strategic goals in a time frame of longer than one year.

We also examine the important role of external information during salespeople's risks processing. New product information typically comes to salespeople in aggregated form and is centrally coordinated, as described by a manufacturing company product manager: "Our salespeople really need to be convinced about the added value of new products, how they address the problems and needs of their customers. We invest a lot of resources and time in away days, workshops, training, information meetings, drinks, exclusive trips, et cetera." Managers expect that salespeople become less conservative because information lowers perceived risk through clarifying how the new product benefits customers and "signaling" the company's commitment to the new product (Erdem and Swait 1998). However, in accordance with perceived risk processing theory, we do not posit a direct but a moderating effect of new product information as it influences how employees act on their perceived risk dimensions (Conchar et al. 2004).

Finally, we account for three categories of evaluation standards that previous perceived risk processing studies have outlined. First, individual preferences toward risk are captured in self-confidence (Conchar et al. 2004; Mitchell 1999), company tenure (Wang 2015), and past performance (Sitkin and Pablo 1992). These factors provide an individual with evidence from past or enduring abilities to overcome obstacles and therefore drive individuals to accept risks that others would avoid (Wiseman and Gomez-Mejia 1998). Second, people are more or less likely to take risk as a function of their past investments and resultant current asset levels; individuals with more favorable current assets are more likely to avoid risky choices (Conchar et al. 2004). We thus consider a salesperson's pay scale and customer relationship quality (i.e., the salesperson's perceptions of his/her customers' trust in, satisfaction with, and commitment to $\mathrm{him} / \mathrm{her}$ ) to represent past investments and achievements within the company and its customer base, respectively. Third, individual risk taking depends on whether problems are presented as gains or losses (Kahneman and Tversky 1979). In our context, a radically new product may also offer much value to customers. We define new product advantage as the salesperson's perception of product superiority relative to existing products with respect to quality, cost-benefit ratio, or technological innovativeness, and account for the possibility that such perceptions may affect risk behavior.

In sum, Fig. 1 presents our conceptual model. We describe our hypotheses next.

\section{Hypotheses}

\section{Perceived risk dimensions in risk assessment}

Perceived performance risk Compared to new products that contain familiar features and benefits, radically new products 
that associate with changes in a customer's established usage patterns and habits carry a high performance risk for salespeople. There is more uncertainty as to whether the customer will adopt the new product (Atuahene-Gima 1997), and standardized sales procedures do not suit radically new products; these require intense, tailored sales efforts (Song and MontoyaWeiss 1998). The selling process of radically new products will thus be perceived as more complex than the selling process of less radically new products. As salespeople strive to maximize their performance through the path of least resistance (Allcott and Sweeney 2016), new product radicalness makes salespeople more likely to delay their engagement in risky sales choices and first expend effort to sell an existing product. We therefore hypothesize:

H1: New product radicalness is positively related to CSB.

Perceived social risk For salespeople, their sales manager is influential because of his or her formal status, personal contact, and pivotal role in individuals' overall performance evaluations (Wieseke et al. 2008). Salespeople interpret managerial orientations through an iterative process of receiving inputs, acting upon demands, and adjusting their behavior due to the feedback received (Schneider et al. 2003). The stronger a manager's new product orientation, the more clearly employees perceive strong expectations to explore new sales routines and to accept the chance of failure. In fact, salespeople know that not engaging in the risky choice of selling new products will change how a sales manager thinks about them. To avoid this high social risk, salespeople are more likely to first explore new product selling options rather than trying to sell customers an existing product. We therefore hypothesize:

$\mathrm{H} 2$ : Managerial new product orientation is negatively related to CSB.

Perceived financial risk Long-term rewards communicate to salespeople the importance of realizing the firm's longterm revenue growth and taking a long-term perspective in responding to customers' needs and wants (Wei and Atuahene-Gima 2009). Compared to short-term rewards such as order intake targets, long-term rewards carry less perceived financial risk because even after a time period

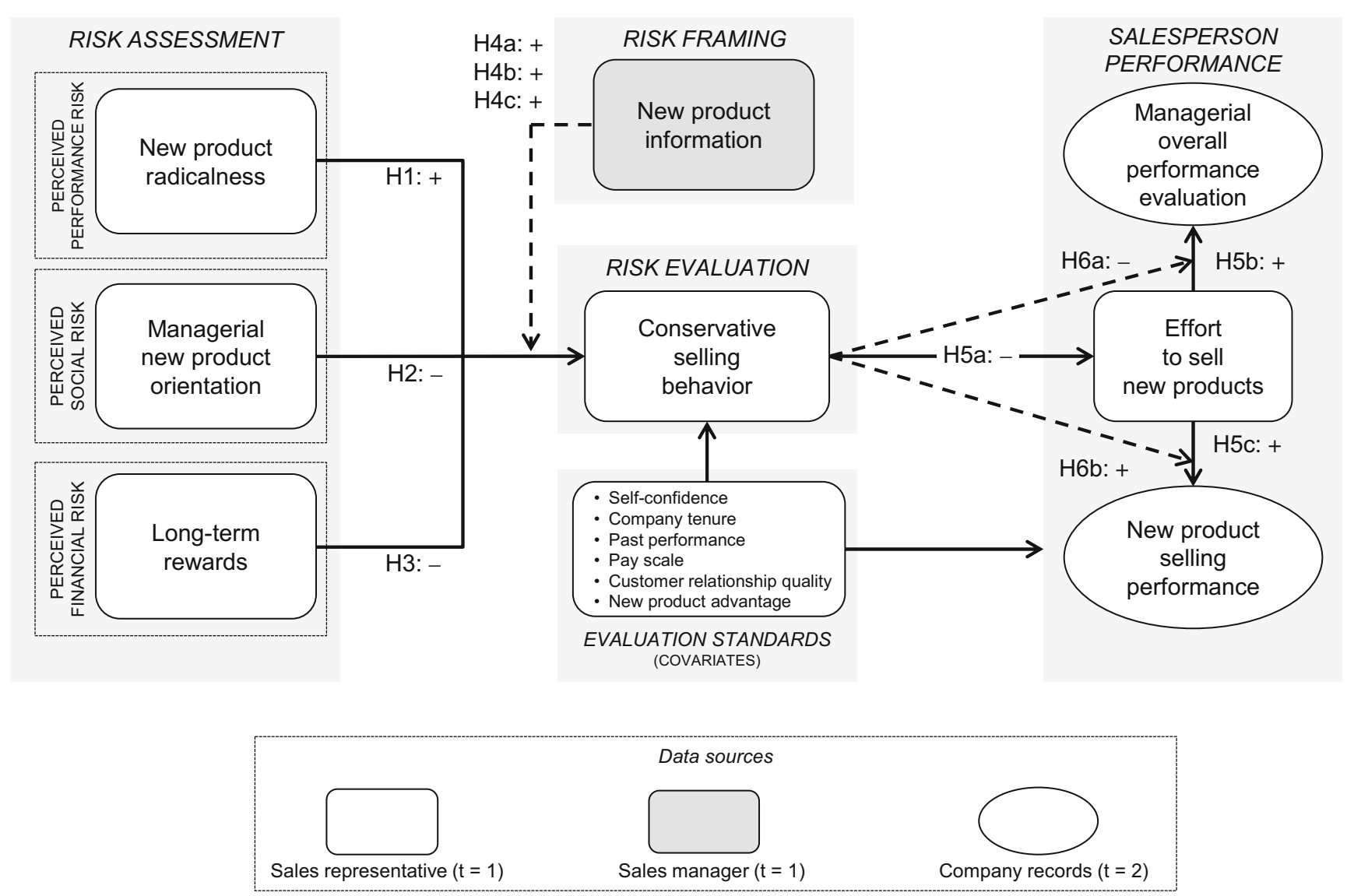

Fig. 1 Hypothesized model 
of personal underperforming, a sales rep has many occasions to restore his or her contribution to revenue growth and receive the sales reward. The lower perceived financial risk makes it more likely that salespeople make selling the new product their first choice in sales cycles, especially because they understand that "new products constitute the lifeblood of long-term firm success" (Mullins et al. 1999, p. 282). In contrast, short-term rewards pressurize salespeople to pursue immediate outcomes, which are perceived to be more easily attained by prioritizing proven sellers over complex new offerings (Ahearne et al. 2010). We therefore hypothesize:

H3: Long-term rewards are negatively related to CSB.

\section{New product information as risk-framing mechanism}

An individual's risk perceptions, information processing, and risky choice are inextricably linked (e.g., Conchar et al. 2004; Dowling and Staelin 1994). In this nomological network the information available to decision makers determines the relative weight of the perceived risk dimensions through a process of cognitive priming (Mandel 2003). Priming an individual with a specific information cue creates cognitive activation tags. When individuals assess risky choice situations, the perceived risk dimensions have to "make contact with one of the tags left earlier and find an intersection" (Collins and Loftus 1975, p. 409). These intersections are easily available and retrievable at the time a risky decision has to be made and thereby affect the weight of perceived risk dimensions in an individual's choice (Mandel 2003; Scheufele and Tewksbury 2007).

The dimension that most closely corresponds to the primed information becomes more important relative to other dimensions. New product information specifically addresses how the new product and its features satisfy customer needs. Rather than stressing social or financial elements in risky situations, managers provide new product information in an effort to reassure salespeople that the product will perform well in the market (AtuaheneGima 1997). It therefore appeals to the salesperson's perception of performance risk. Providing new product information to salespeople will strengthen the relationship between perceived performance risk and CSB and weaken the relationships of perceived social risk and perceived financial risk with CSB. Hence, we expect that new product radicalness will become a more important antecedent and managerial new product orientation and long-term rewards become less important antecedents of CSB. Formally:

H4: New product information (a) strengthens the relationship between new product radicalness and CSB, and weakens the relationships (b) between managerial new product orientation and CSB and (c) between long-term rewards and CSB.

\section{Risk evaluation outcomes: CSB's performance consequences}

Previous research has convincingly demonstrated that higher levels of salesperson's effort to sell new products leads to positive performance outcomes (Johnson and Sohi 2016). Reasons include that a high level of effort conveys to customers the value of the product and the salesperson's confidence in the product (Ahearne et al. 2010) and being more persistent helps overcome occasional setbacks and thus closing deals (Fu et al. 2009). Effort to sell new products also positively relates to a manager's overall performance evaluation, as it signifies that salespeople are willing to go the extra mile and do not refrain from engaging in difficult selling tasks. Harris et al. (2014) even report that sales managers may prefer hard work and productivity over a salesperson's intentions to satisfy customer needs. Although disconcerting from a marketing point of view, it shows the importance of salesperson effort in managerial evaluations of their subordinates' performance.

When salespeople display CSB and thus delay their efforts to sell the new product during and across customer encounters, the resources remaining for intensively selling the new product in the end are more limited because of the shorter time period available. In addition, people revising their initial choice from a set of options need some time to recalibrate because of cognitive processes such as dissonance, rationalization, anticipated regret, or inertia (Hoch 2002). Salespeople who (have to) switch their selling efforts from existing to new products may therefore only grudgingly accept their new strategy. Their overall effort to sell new products will therefore be lower. In sum, we expect that effort to sell new products will mediate between CSB and performance outcomes. Formally:

H5: Effort mediates the relationship between CSB and performance outcomes such that (a) CSB negatively relates to effort to sell new products, and effort to sell new products positively relates to (b) managerial overall 
performance evaluation and (c) new product selling performance.

Salespeople are rational actors who allocate their cognitive and physical resources across a portfolio of products in a way that maximizes overall performance (Ahearne et al. 2010). This implies that they may plan and organize their selling activities in a way that makes sales efforts more effective (Allcott and Sweeney 2016; Rapp et al. 2006). One approach for salespeople to structure their selling activities is to change the order in which different products from the product portfolio are presented to the customer. We thus posit that conservative selling can be a strategy that combines with effort to sell new products to affect a salesperson's performance outcomes. ${ }^{2}$

First, we expect that CSB dampens the positive relationship between effort to sell new products and overall managerial performance evaluation. Managers assess their subordinates by judging the degree to which a salesperson matches their ideal of a "good salesperson." This is typically reflected in high effort and productivity (Harris et al. 2014). When launching new products, managers expect this effort to be enduring because salespeople need to open up a new market by informing and educating customers about how the new product may address customer needs and problems ( $\mathrm{Fu}$ et al. 2010). When salespeople first focus on selling existing products and delay their effort to sell the new product till the late stages of sales cycles, managers will feel that their employees had the chance to put in more effort to sell the new product but did not take this opportunity. Additional effort that employees put into selling new products after a period of conservatism thus translates less strongly into managerial evaluations. In contrast, when salespeople expend effort in selling new products throughout the sales cycle, managers may feel that employees constantly took initiative and were competitive in selling new products (Pettijohn et al. 2001). Because the sales activities of such employees lack a period where no effort was expended on selling the new product, managers are less likely to think that more effort could have been put in. Each additional unit of effort is then appreciated more because managers feel

\footnotetext{
${ }^{2}$ From a methodological perspective, we note that previous research points out that the independent variable can also act as a moderator of the mediating effect (Preacher et al. 2007). In such cases the independent variable produces its effect in part by changing the mediating process that normally produces the outcome (Judd and Kenny 1981). In our case it is expected that CSB changes the way in which other stakeholders (i.e., managers and customers) perceive high levels of effort, thereby leading to different outcomes.
}

that employees may have reached their cognitive and physical limits and now go the extra mile.

Second, we expect that CSB strengthens the positive relationship between effort to sell new products and new product selling performance. Because CSB indicates the extent to which a salesperson maximizes selling efforts for existing products before engaging in efforts to sell the new product, customers likely experience a sequential presentation of products in a sales cycle with a salesperson who acts conservatively. Literature supports the notion that new products become more attractive when presented following existing products. For instance, sales literature in consumer settings suggests that foot-in-the-door techniques can help lower initial resistance to adopt because in their strive for consistent responses, customers agreeing to a small initial request are more likely to comply with a larger or riskier request (Cialdini and Guadagno 2004). Sequential presentation also makes a new product look more attractive to a customer; compared to an existing product, each additional feature of a new product may add desired capabilities and thus provide the customer with another reason to purchase (Thompson et al. 2005). This makes the effort spent on selling the new product more effective. In sum, we posit:

H6: CSB moderates the relationship between effort to sell new products and performance outcomes, such that CSB (a) weakens the positive effect of effort to sell new products on managerial overall performance evaluation and (b) strengthens the positive effect of effort to sell new products on new product selling performance.

\section{Method}

\section{Research context and data collection}

Following our qualitative grounding discussed earlier, for Sample 1 we gathered data from a global ICT company that operates in 90 countries and is representative of B2B selling contexts as (1) new products are introduced annually, (2) new products are complex and break from existing offerings, (3) the salesforce organization is unit-based, and (4) selling is a relational rather than a transactional activity. The company's product portfolio consists of workspace management systems, connectivity solutions, and datacenters, among others. Such products have a relatively short life cycle.

The company's sales force focuses on a set of approximately 500 business customers in industries such as finance, 
government, education, transport, and retail. At the time of study, the company had just introduced several new solutions that required significant changes in customers' work processes. The radicalness of these solutions differed across sectors; not every sector faced equally substantial changes to their work processes. The new products immediately entered the salespeople's product portfolios and accounted for a substantial portion of the company's total annual revenue $(28 \%)$. Sales units received collective briefings and training about the new product's features, value proposition, and link with customer needs.

We collected data from three sources at different points in time. We asked all 244 salespeople and their 31 managers, organized in 31 sales units, to complete a questionnaire. After two reminders, sent over a three-week period, we received 172 responses from salespeople ( $70.5 \%$ response rate) and 31 responses from managers (100\% response rate). All units sampled featured at least 3 responding salespeople. Six months after collecting the questionnaire data, we obtained performance data from company records.

\section{Measures}

With minor wording adjustments to enhance the applicability of some items, most of our constructs could be operationalized with scales validated in previous work. However, because CSB is a new concept, we carefully considered its operationalization. Following our review of relevant literature and general qualitative grounding, we interviewed four sales managers of our focal company and asked them to reflect on their experiences with new product launches in the salesforce and what actions they typically associate with salesperson conservatism. The managers consistently mentioned elements such as being cautious, sticking to existing sales routines, and preferring to maximize the potential of proven sellers first.

Based on the managers' input and studies on political (e.g., Jost et al. 2003) and accounting (e.g., Watts 2003) conservatism, we developed an item pool. We conducted industryspecific investigations to define the average product life cycle and sales process duration. As a result, items referred to "new products" when those were introduced in the 12 months preceding the questionnaire. The initial pool of items was then refined based on further in-depth interviews with the sales managers, their salespeople, and their sales support staff. Next, we constructed a draft questionnaire and pretested it with six company employees and two industry experts. Following the pretests, we made minor wording adjustments to enhance the applicability of the items. The resulting scale consists of three items.

Table 2 contains the scale items for our measures. All responses were recorded on five-point Likert scales with 1 ("strongly disagree") and 5 ("strongly agree") as anchors. To assess new product information, sales managers completed four items adapted from Low and Mohr (2001) to indicate the extent to which the salespeople in their unit received timely, relevant, and accurate information on how new products address customer needs. It is therefore a unit-level measure.

The salesperson questionnaire included managerial new product orientation, measured with five items from Van der Borgh and Schepers (2014). Long-term rewards was measured with three items adopted from Wei and Atuahene-Gima (2009) such that a low score on these items indicate a focus on short-term rewards. New product radicalness was measured using a four-item scale developed by Langerak et al. (2008), and effort to sell new products was based on work by Sujan et al. (1994) and Hultink and Atuahene-Gima (2000).

New product selling performance was taken from company records and reflects for each salesperson the sales volume generated from the sale of new products as a percentage of his/her overall sales volume. Managerial overall performance evaluation was also collected from company records as we were given access to an aggregate measure of managers' formal evaluations of each salesperson's overall functioning. Sub dimensions tapped into individual performance in terms of output and behavior and included questions as "This salesperson obtained revenue targets for his or her customers," "This salesperson sticks to the company's formal rules and regulations," and "This salesperson contributes to the company's success." For each employee, the aggregated score indicated a "poor" (1) to "excellent" (5) evaluation.

We controlled for the evaluation standards that salespeople may use in their risk evaluation phase. Specifically, we measured self-confidence with one item from Riggs and Knight (1994). In addition, company tenure (i.e., years with the firm), past performance (i.e., order intake target obtained on all products in previous year), and pay scale (i.e., a marketbased salary structure dividing sales people in different levels of salary relative to the market) were obtained from company databases. Customer relationship quality was measured with four items from Palmatier (2008), and new product advantage was measured using a four-item scale developed by Langerak et al. (2008).

\section{Analyses}

\section{Analytical approach}

Because salespeople were nested within sales units, responses from salespeople of the same unit may be interdependent. To determine whether we should explicitly account for multiple levels in our analyses, we examined the intraclass correlation coefficients (ICC) for the variables in our model; ICCs ranged from .025 to .176. Even small ICC values (e.g., .05) indicate that researchers should control for dependence of observations 
to prevent considerable bias in the results (Cohen et al. 2003, p. 538). We thus accounted for the multilevel structure of our data and estimated a multilevel structural equation model (MSEM) with Mplus 7.11 software (Muthén and Muthén 2012). Compared to regression-based multilevel approaches, MSEM has the advantage not to conflate within- and betweengroup effects. MSEM separates the effects using latent variables at both levels and thereby accounts for measurement error (Preacher et al. 2010).

Finally, we obtained a relatively small sample and set out to test moderated and mediated effects that are non-normally distributed. Given these conditions we employed Bayesian methods because these provide more reliable estimations on small samples (Muthén and Asparouhov 2012) and do not assume or require normal distributions for the model parameters (Zhang et al. 2009).

\section{Measurement model analysis}

To test whether the data fit the hypothesized measurement model, we conducted a confirmatory factor analysis (CFA) that accounted for the non-identification problem that may occur with small sample sizes (i.e., the CFA is Bayesian) and that considered the nested nature of our data (i.e., the CFA is multi-level). Table 2 reports the results. ${ }^{3}$

To determine the Bayesian CFA model fit, we examined the posterior predictive $\mathrm{p}$ (ppp) value. Our BCFA showed a ppp-value of .862, which indicated a good fit between the

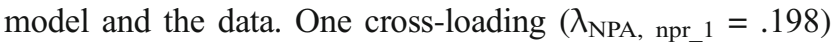
and four residual covariances $\left(\sigma_{\text {npo_3,npo_4 }}=-.129\right.$; $\sigma_{\text {ltr_ } 1 \text {,ltr_ } 3}=-.149 ; \sigma_{\text {eff_2,eff_3 }}=.055 ; \sigma_{\text {eff_ } 4 \text {,eff_5 } 5}=.075$ ) were found significant, which warrants the use of Bayesian estimation techniques (i.e., subscript capitals indicate latent constructs, lower case indicates items. Please refer to Tables 2 and 3 for details on the acronyms).

All items loaded on their respective factors with substantial values, and no serious cross-loadings (i.e., $>.3$ ) were observed. Table 3 shows that the scales also achieved sufficient reliability, with Cronbach's alphas varying between .73 and

\footnotetext{
$\overline{3}$ Consistent with Muthén and Asparouhov (2012), our CFA employed an inverse-Wishart prior, IW(I, df) with $\mathrm{df}=\mathrm{p}+6=35$, which corresponds to prior means and standard deviations for residual covariances of 0 and .01 , respectively. Thus, we specified informative priors for cross-loadings with the prior distributions $\mathrm{N}(0, .01)$. To reduce any auto-correlation problems among Markov Chain Monte Carlo (MCMC) iterations, we used a thinning of 10 with a total of 100,000 iterations to describe the posterior distributions. We relied on a burn-in of 50,000 draws to reach a stationary posterior distribution. We confirmed the convergence of the Gibbs sampling by examining the trace plot of the Markov chains and the Gelman-Rubin potential scale reduction statistic (PSR). The posterior parameter draws indicated convergence and stability after hundreds of draws (i.e., PSR < 1.002). To assess whether our Bayesian procedure affected the outcomes of the CFA, we ran an alternative maximum likelihood CFA. Results indicated a consistent pattern of items loadings.
}

.93 and composite reliabilities varying between .82 and .94 . Average variances extracted (AVE) exceeded .50 for each construct, in support of convergent validity. The constructs also displayed discriminant validity because the AVE of each construct exceeded the average variance shared with any other construct.

We evaluated the validity of our CSB concept and scale in Sample 1 using a second dataset (Sample 2) obtained from a commercially available panel of 191 B2B salespeople. The CSB scale again displayed desirable psychometric properties and satisfied the criteria for discriminant validity versus related concepts. Appendix A provides more detail.

\section{Structural model analysis}

We tested our hypothesized model using Sample 1 and took a stepwise approach. In the first step, we included the control variables and our hypothesized direct effects (Model 1). In the second step, we specified and added the interaction effects of unit-level new product information (Model 2). We standardized all independent variables before creating the product terms to enable model convergence and facilitate the interpretation of the coefficients without altering the underlying data. Thus, we obtained the following multilevel equations:

$$
\begin{aligned}
\mathrm{CSB}_{i j} & =\gamma_{00}+\gamma_{10} \mathrm{NPO}_{i j}+\gamma_{20} \mathrm{LTR}_{i j}+\gamma_{30} \mathrm{NPR}_{i j}+\gamma_{01} \mathrm{NPI}_{j} \\
& +\gamma_{40}\left(\mathrm{NPO}_{i j} \times \mathrm{NPI}_{j}\right)_{i j}+\gamma_{50}\left(\mathrm{LTR}_{i j} \times \mathrm{NPI}_{j}\right)_{i j} \\
& +\gamma_{60}\left(\mathrm{NPR}_{i j} \times \mathrm{NPI}_{j}\right)_{i j}+\gamma_{70} \mathrm{TEN}_{i j}+\gamma_{80} \mathrm{PP}_{i j} \\
& +\gamma_{90} \mathrm{PAY}_{i j}+\gamma_{100} \mathrm{CRQ}_{i j}+\gamma_{110} \mathrm{NPA}_{i j}+\gamma_{120} \mathrm{SCF}_{i j} \\
& +\mathrm{u}_{0 j}+\mathrm{e}_{i j} \\
\mathrm{EFF}_{i j} & =\alpha_{00}+\alpha_{10} \mathrm{NPO}_{\mathrm{ij}}+\alpha_{20} \mathrm{LTR}_{i j}+\alpha_{30} \mathrm{NPR}_{i j} \\
& +\alpha_{40} \mathrm{CSB}_{i j}+\alpha_{01} \mathrm{NPI}_{j}+\alpha_{80} \mathrm{TEN}_{i j}+\alpha_{90} \mathrm{PP}_{i j} \\
& +\alpha_{100} \mathrm{PAY}_{i j}+\alpha_{110} \mathrm{CRQ}_{i j}+\alpha_{120} \mathrm{NPA}_{i j} \\
& +\gamma_{130} \mathrm{SCF}_{i j}+\pi_{0 j}+\varepsilon_{i j} \\
& +\gamma_{120} \mathrm{SCF}_{i j}+\mu_{0 h j}+\epsilon_{h i j} \\
& +\theta_{40}\left(\mathrm{CSB}_{i j} \times \mathrm{EFF}_{j}\right)_{i j}+\theta_{70} \mathrm{TEN}_{i j}+\theta_{80} \mathrm{PP}_{i j} \\
\mathrm{SPO}_{i j} & =\theta_{00}+\theta_{10} \mathrm{CSB}_{i j}+\theta_{20} \mathrm{EFF}_{i j} \\
& +\theta_{100} \mathrm{CRQ}_{i j}+\theta_{110} \mathrm{NPA}_{i j} \\
& \\
&
\end{aligned}
$$

$\mathrm{SPO}_{\mathrm{ij}}$ indicates salesperson performance outcome for salesperson $\mathrm{i}$ of unit $\mathrm{j}$, other acronyms are explained in Table 3. Furthermore, $\gamma_{00}, \alpha_{00}$, and $\theta_{00}$ are intercepts; $\gamma_{10} \ldots \theta_{110}$ are regression coefficients; $\mathrm{e}_{\mathrm{ij}}, \varepsilon_{\mathrm{ij}}$, and $\epsilon_{\mathrm{ij}}$, are individual-level error 
Table 2 Main construct scale measures and factor loadings

Construct / item

New product information (adopted from Low and Mohr 2001)

[Manager rated] Please consider the new products X, Y, and Z that were introduced in the product portfolio of the sales team you

supervised during the past 12 months and answer the following statements.

1 The new product information communicated about customer needs was very reliable. (npi_1)

2 The provided new product information included important details about customer needs. (npi_2)

3 The new product information provided was accurate. (npi_3)

4 The new product information was provided in a timely manner. (npi_4)

New product radicalness (adopted from Langerak et al. 2008)

The new products of [company]...

1 involve high change over costs for my customers. (npr_1)

2 are difficult for my customers to understand or evaluate. (npr_2)

3 take my customers time to really understand their advantages. (npr_3)

4 require advance planning by my customers. (npr_4)

Managerial new product orientation (adopted from Van der Borgh and Schepers 2014)

My sales manager wants us to devote our time and attention primarily to. . .

1 the selling of new products and services in our assortment. (npo_1)

2 the development of a sales argument for the new products and services. (npo_2)

3 experimenting with the selling tactics for the new products and services. (npo_3)

4 the utilization of new selling opportunities for new products. (npo_4)

5 spot new, rising needs of customers. (npo 5)

Long-term rewards (adopted from Wei and Atuahene-Gima 2009)

1 I am strongly motivated by the pay system to take a long-term orientation (e.g., revenue growth). (1tr_1) .87

2 Our pay policies make it possible to achieve long-term (1 or more years) goals. (1tr_2) .90

3 Our pay policies make me keenly aware that long-term results (e.g., revenue growth) are more important than short-term results (e.g., .84 order intake). (1tr_3)

Effort to sell new products (based on Sujan et al. 1994 and Hultink and Atuahene-Gima 2000)

When I engage in the activity of new product selling, I...

1 always take the initiative. (eff_1)

2 do not give up easily when encountering a customer to whom it is difficult to sell new products. (eff_2)

3 always anticipate and act upon potential problems. (eff_3)

4 am constantly on the lookout to identify opportunities. (eff_4)

5 actively scan emerging needs. (eff_5)

Conservative selling behavior (new scale)

Please consider the new products that were introduced in your product portfolio during the past 12 months and answer the following statements. Over the past 12 months, I...

1 always tried to maximize my selling efforts for existing products before considering the new products. (csb_1)

2 preferred selling existing products above selling new products. (csb_2)

terms; and $\mathrm{u}_{\mathrm{oj}}, \pi_{\mathrm{oj}}$, and $\mu_{\mathrm{oj}}$ are unique variations of unit $\mathrm{j}$ from the intercept (i.e., $\gamma_{00}, \alpha_{00}$, and $\theta_{00}$ ), after partialling out the effects of all unit-level regression coefficients (i.e., $\gamma_{01}, \alpha_{01}$ ). We then proceeded with our Bayesian estimation procedure. ${ }^{4}$

\footnotetext{
${ }^{4}$ For the Bayesian estimator we assumed normal $\mathrm{N}\left(0,10^{4}\right)$ prior distributions for all regression coefficients and inverse gamma $\operatorname{IG}\left(10^{-3}, 10^{-3}\right)$ prior distributions for the variance parameters. Similar to the Bayesian CFA procedure, we used a total of 100,000 iterations, a burn-in of 50,000 draws, a thinning of 10 , and confirmed the convergence and stability of the iterations by examining trace plots and potential scale reduction (PSR) statistics
}

\section{Results}

\section{Antecedents of CSB}

Tables $4 \mathrm{a}$ and $4 \mathrm{~b}$ displays the results of the estimations of our two models. Model 2 explained significantly more variation than Model 1. In support of $\mathrm{H} 1$, we found a direct positive effect of new product radicalness on $\mathrm{CSB}\left(\mathrm{CI}_{95 \%}=[.02 ; .31]\right)$. The results also confirm $\mathrm{H} 2$, as the effect of managerial new 
Table 3 Construct reliabilities and correlations

\begin{tabular}{|c|c|c|c|c|c|c|c|c|c|c|c|c|c|c|c|}
\hline & & 1. & 2. & 3. & 4. & 5. & 6. & 7. & 8. & 9. & 10. & 11. & 12. & 13. & 14. \\
\hline 1. & Company tenure (TEN) & 1.00 & & & & & & & & & & & & & \\
\hline 2. & Past performance (PP) & -.04 & 1.00 & & & & & & & & & & & & \\
\hline 3. & Pay scale (PAY) & -.06 & .11 & 1.00 & & & & & & & & & & & \\
\hline 4. & Self-confidence (SCF) & -.07 & .01 & .13 & 1.00 & & & & & & & & & & \\
\hline 5. & Customer rel. quality (CRQ) & -.11 & .04 & .14 & .10 & 1.00 & & & & & & & & & \\
\hline 6. & New product advantage (NPA) & .03 & -.09 & -.08 & .08 & .14 & 1.00 & & & & & & & & \\
\hline 7. & Managerial new product orient. (NPO) & -.08 & .07 & -.13 & .01 & .11 & $.21 * *$ & 1.00 & & & & & & & \\
\hline 8. & Long-term rewards (LTR) & .02 & .01 & -.03 & .05 & $.22 * *$ & .10 & $.30 * *$ & 1.00 & & & & & & \\
\hline 9. & New product radicalness (NPR) & -.06 & .02 & .11 & .05 & .09 & -.03 & -.08 & -.12 & 1.00 & & & & & \\
\hline 10. & New product information (NPI) ${ }^{a}$ & $-.17 *$ & -.12 & .01 & $.16^{*}$ & .03 & .04 & -.02 & -.06 & .10 & 1.00 & & & & \\
\hline 11. & Conservative selling behavior (CSB) & .13 & .09 & .08 & $-.15 * *$ & .04 & -.07 & $-.16^{*}$ & .03 & $.20 *$ & .06 & 1.00 & & & \\
\hline 12. & Effort to sell new products (EFF) & -.13 & .03 & -.01 & $.30 * *$ & $.22 * *$ & .08 & $.18^{*}$ & -.01 & -.08 & .10 & $-.26 * *$ & 1.00 & & \\
\hline 13. & Managerial overall perf. evaluation & .08 & $.27 * *$ & .05 & .05 & .03 & -.08 & .02 & .14 & .00 & -.06 & .03 & $.24 * *$ & 1.00 & \\
\hline \multirow[t]{6}{*}{14.} & $\%$ Sales volume obtained & -.04 & .05 & -.03 & .02 & .07 & $.23 * *$ & $.19^{*}$ & .11 & -.09 & $-.26^{* *}$ & -.04 & $.20 * *$ & .13 & 1.00 \\
\hline & Mean & 3.3 & 178.3 & 11.7 & 4.2 & 4.1 & 3.5 & 3.7 & 2.8 & 3.4 & 3.0 & 2.4 & 4.2 & 3.1 & 23.8 \\
\hline & Std. Deviation & 5.3 & 99.2 & 1.0 & .7 & .7 & .7 & .8 & 1.1 & .7 & 1.0 & .9 & .8 & .6 & 23.4 \\
\hline & $\alpha$ & & & & & .87 & .79 & .83 & .86 & .73 & .92 & .83 & .93 & & \\
\hline & $\rho$ & & & & & .90 & .84 & .88 & .91 & .82 & .94 & .89 & .94 & & \\
\hline & AVE & & & & & .68 & .57 & .59 & .76 & .54 & .79 & .73 & .75 & & \\
\hline
\end{tabular}

$n=172$ salespeople in $N=31$ sales units

$* * p<.01$ (two-tailed). $* p<.05$ (two-tailed)

${ }^{\text {a }}$ Group-level variables; $N=31$ observations

product orientation on CSB is significant and negative $\left(\mathrm{CI}_{95 \%}=[-.33 ;-.01]\right)$. The main effect of long-term rewards on CSB is significant and positive $\left(\mathrm{CI}_{95 \%}=[.03 ; .29]\right)$, while the hypothesized effect was negative. This is an interesting finding; we return to this result and discuss potential explanations below. Hence, despite the significant relationship have to reject $\mathrm{H} 3$.

We now turn to the moderating effects of new product information. The results show a positive interaction effect of new product information and new product radicalness $\left(\mathrm{CI}_{95 \%}=[.04 ; .34]\right)$ toward CSB. In addition, the positive interaction effect of new product information and managerial new product orientation toward CSB was supported by the data $\left(\mathrm{CI}_{95 \%}=[.01 ; .32]\right)$. This confirms H4a and $\mathrm{H} 4 \mathrm{~b}$. The interaction term of new product information and long-term rewards was significant and negative $\left(\mathrm{CI}_{95 \%}=[-.31 ;-.01]\right)$. Because the main effect of longterm rewards on CSB turned out positive, this negative interaction effect aligns with our overall argument that long-term rewards would become a less important driver of CSB following the provision of new product information to the salesforce. Therefore, although we formally reject $\mathrm{H} 4 \mathrm{c}$, we do find empirical support for the dampening effect of new product information expected in the hypothesis. We interpret this effect below.
Panels A, B, and C in Fig. 2 plot the results of the interaction effects to facilitate interpretation. The plots provide the results for values 1 standard deviation below and above the mean of the independent variable and the moderator. Panel A reveals that new product radicalness leads to more CSB when new product information is high. Remarkably, when little new product information is provided to salespeople, there seems to be no effect of new product radicalness on CSB. Panel B shows that under conditions of low new product information the salesperson follows managerial guidance and lowers his/her CSB, presumably because being conservative entails a (too) large perceived social risk. However, when a salesperson receives new product information, the effect of managerial orientation on CSB is neutralized because the perceived performance risk becomes more salient in lieu of perceived social risk.

Finally, Panel $\mathrm{C}$ shows that a similar logic applies to financial risk: when new product information is available, long-term rewards have little effect on CSB because perceived financial risk becomes less salient in individual's risk assessment. Remarkably though, under low information conditions, the effect of long-term rewards is positive. Long-term rewards motivate employees to care about realizing the firm's long-term revenue growth (Wei and 
Table 4a Unstandardized Bayesian estimated coefficients for antecedents and outcomes of CSB ${ }^{\mathrm{a}}$

\begin{tabular}{|c|c|c|c|c|c|c|c|c|c|}
\hline & \multicolumn{6}{|c|}{ Mediator } & \multicolumn{3}{|c|}{ Salesperson performance outcomes } \\
\hline & \multicolumn{6}{|c|}{ Conservative selling behavior } & \multicolumn{3}{|c|}{ Effort to sell new products } \\
\hline & \multicolumn{3}{|c|}{ Model 1: } & \multicolumn{3}{|c|}{ Model 2: } & \multicolumn{3}{|l|}{ Model $2^{\mathrm{b}}$} \\
\hline & \multicolumn{3}{|c|}{ Direct effects only } & \multicolumn{3}{|c|}{ With interactions } & & & \\
\hline & $\mathrm{B}$ & S.D. & 95\% C.I. & $\mathrm{B}$ & S.D. & 95\% C.I. & $\mathrm{B}$ & S.D. & 95\% C.I. \\
\hline Intercept & 1.40 & $(1.06)$ & {$[-.69 ; 3.48]$} & 1.54 & $(1.03)$ & {$[-.49 ; 3.57]$} & -1.625 & $(1.07)$ & {$[-3.75 ; .50]$} \\
\hline \multicolumn{10}{|l|}{ Controls } \\
\hline Company tenure (TEN) & $.16 *$ & $(.08)$ & {$[-.01 ; .31]$} & $.17 *$ & (.08) & {$[.02 ; .32]$} & -.07 & $(.08)$ & {$[-.22 ; .08]$} \\
\hline Past performance (PER) & .09 & $(.08)$ & {$[-.07 ; .25]$} & .05 & $(.08)$ & {$[-.10 ; .21]$} & .05 & $(.08)$ & {$[-.11 ; .20]$} \\
\hline Pay scale (PAY) & .10 & $(.10)$ & {$[-.09 ; .30]$} & .08 & $(.10)$ & {$[-.11 ; .28]$} & -.05 & $(.09)$ & {$[-.23 ; .13]$} \\
\hline Self-confidence (SCF) & $-.27 * *$ & (.11) & {$[-.48 ;-.07]$} & $-.29 * *$ & (.10) & {$[-.49 ;-.08]$} & $.38 * *$ & (.11) & {$[.17 ; .59]$} \\
\hline Customer rel. Quality (CRQ) & .05 & $(.08)$ & {$[-.11 ; .21]$} & .08 & $(.08)$ & {$[-.07 ; .23]$} & $.22 * *$ & (.08) & {$[.07 ; .38]$} \\
\hline New product advantage (NPA) & -.07 & $(.08)$ & {$[-.23 ; .10]$} & -.05 & $(.08)$ & {$[-.21 ; .11]$} & .04 & $(.08)$ & {$[-.12 ; .20]$} \\
\hline \multicolumn{10}{|l|}{ Simple effects } \\
\hline New product radicalness (NPR) & $.21 * *$ & $(.08)$ & {$[.05 ; .37]$} & $.18^{*}$ & (.08) & {$[.02 ; .31]$} & -.08 & $(.08)$ & {$[-.24 ; .08]$} \\
\hline Managerial new product orientation (NPO) & -.09 & $(.08)$ & {$[-.26 ; .08]$} & $-.16 *$ & $(.09)$ & {$[-.33 ; .-01]$} & .12 & $(.08)$ & {$[-.04 ; .28]$} \\
\hline Long-term rewards (LTR) & .12 & $(.08)$ & {$[-.05 ; .28]$} & $.14^{*}$ & $(.07)$ & {$[.03 ; .29]$} & -.08 & $(.08)$ & {$[-.24 ; .08]$} \\
\hline New product information ${ }^{\mathrm{c}}(\mathrm{NPI})$ & .15 & $(.12)$ & {$[-.09 ; .37]$} & .14 & $(.11)$ & {$[-.09 ; .36]$} & .11 & $(.47)$ & {$[-.45 ; .63]$} \\
\hline Conservative selling behavior (CSB) & & & & & & & $-.17 *$ & (.08) & {$[-.33 ;-.01]$} \\
\hline \multicolumn{10}{|l|}{ Cross-level interaction } \\
\hline NPR $x$ NPI & & & & $.19 * *$ & $(.08)$ & {$[.04 ; .34]$} & & & \\
\hline NPO $x$ NPI & & & & $.16^{*}$ & $(.08)$ & {$[.01 ; .32]$} & & & \\
\hline LTR x NPI & & & & $-.16 *$ & $(.08)$ & {$[-.31 ;-.01]$} & & & \\
\hline $\mathrm{R}^{2}$ & $19.1 \%$ & & & $28.5 \%$ & & & $25.7 \%$ & & \\
\hline
\end{tabular}

Boldface type indicates that the $95 \%$ posterior credibility interval (C.I.) does not include zero. S.D. $=$ Posterior standard deviation

$*=p<.05$ (one-tailed); $* *=p<.01$ (one-tailed)

${ }^{a}$ We conducted robustness checks to rule out alternative explanations. However, inclusion of either group-level CSB (as an additional motivation to exert CSB) or structural market elements (see section on Robustness of results) did not alter our initial findings. For reasons of parsimony, we decided not to report them here. More information about the robustness checks is available from the first author upon request

${ }^{\mathrm{b}}$ For effort to sell new products, we only report the results of Model 2. They are similar to those of Model 1 because we did not hypothesize cross-level interaction effects with effort to sell new products as a dependent variable. However, as an exploratory analysis, we estimated a model regressing effort on all interaction effects. This did not change results

${ }^{\mathrm{c}}$ Unit level measure

Atuahene-Gima 2009). This goal can be accomplished through the sales of any product in a salesperson's portfolio. Because salespeople more easily see how to realize revenue growth through proven sellers than through difficult-to-sell new products (Wieseke et al. 2008), long-term rewards could perhaps de-emphasize salespeople's concerns about a new product's success in the market. An alternative explanation is that long-term rewards and new product information substitute each other: when salespeople have sufficient information, there is no need for long-term rewards since salespeople are able to make well-informed decisions.

Overall, Fig. 2 shows three distinct moderating effects (cf. Cohen et al. 2003). Paired with new product radicalness, new product information has a synergetic (or enhancing) effect on $\mathrm{CSB}$, paired with managerial new product orientation it has a buffering effect, and paired with long-term rewards it has a substitution (or antagonistic) effect. 
Table 4b Unstandardized Bayesian estimated coefficients for antecedents and outcomes of CSB

\begin{tabular}{|c|c|c|c|c|c|c|c|c|c|c|c|c|}
\hline & \multicolumn{12}{|c|}{ Salesperson performance outcomes } \\
\hline & \multicolumn{6}{|c|}{ Managerial overall performance evaluation } & \multicolumn{6}{|c|}{$\%$ Sales volume obtained } \\
\hline & \multicolumn{3}{|c|}{ Model 1: } & \multicolumn{3}{|c|}{ Model 2: } & \multicolumn{3}{|c|}{ Model 1: } & \multicolumn{3}{|c|}{ Model 2: } \\
\hline & \multicolumn{3}{|c|}{ Direct effects only } & \multicolumn{3}{|c|}{ With interactions } & \multicolumn{3}{|c|}{ Direct effects only } & \multicolumn{3}{|c|}{ With interactions } \\
\hline & $\mathrm{B}$ & S.D. & 95\% C.I. & $\mathrm{B}$ & S.D. & 95\% C.I. & $\mathrm{B}$ & S.D. & 95\% C.I. & $\mathrm{B}$ & S.D. & 95\% C.I. \\
\hline Intercept & $3.32 * *$ & (.63) & {$[2.08 ; 4.57]$} & $3.23 * *$ & (.63) & {$[1.98 ; 4.48]$} & $43.44 *$ & (26.45) & {$[8.79 ; 95.68]$} & $50.31 *$ & (26.16) & {$[1.35 ; 98.97]$} \\
\hline \multicolumn{13}{|c|}{ ] } \\
\hline Company tenure (TEN) & .05 & $(.05)$ & {$[-.04 ; .15]$} & .04 & $(.05)$ & {$[-.05 ; .14]$} & -1.16 & (1.94) & {$[-5.42 ; 2.21]$} & -1.18 & (1.94) & {$[-5.00 ; 2.63]$} \\
\hline Past performance (PER) & $.15^{*}$ & (.05) & {$[.05 ; .24]$} & $.14^{* *}$ & (.05) & {$[.04 ; .23]$} & -.99 & $(1.98)$ & {$[-4.89 ; 2.87]$} & -.57 & $(1.97)$ & {$[-4.45 ; 3.28]$} \\
\hline Pay scale (PAY) & .04 & $(.06)$ & {$[-.07 ; .16]$} & .04 & $(.06)$ & {$[-.07 ; .16]$} & .49 & $(2.31)$ & {$[-4.02 ; 5.07]$} & .57 & $(2.30)$ & {$[-3.92 ; 5.12]$} \\
\hline Self-confidence (SCF) & .01 & $(.07)$ & {$[-.12 ; .14]$} & .02 & $(.07)$ & {$[-.11 ; .16]$} & 1.17 & $(2.77)$ & {$[-4.27 ; 6.59]$} & .47 & $(2.77)$ & {$[-4.95 ; 5.91]$} \\
\hline \multicolumn{13}{|l|}{ Simple effects } \\
\hline Effort to sell new products (EFF) & $.16^{* *}$ & (.05) & {$[.06 ; .26]$} & $.15^{* *}$ & $(.05)$ & {$[.05 ; .25]$} & $5.39 * *$ & $(2.02)$ & {$[1.43 ; 9.35]$} & $5.82 * *$ & $(2.01)$ & {$[1.87 ; 9.77]$} \\
\hline $\begin{array}{l}\text { Conservative selling behavior } \\
\text { (CSB) }\end{array}$ & .04 & $(.05)$ & {$[-.06 ; .14]$} & .05 & $(.05)$ & {$[-.05 ; .14]$} & 1.57 & $(2.03)$ & {$[-2.41 ; 5.54]$} & 1.30 & $(2.01)$ & {$[-2.66 ; 5.25]$} \\
\hline \multicolumn{13}{|l|}{ Within-level interaction } \\
\hline CSB x EFF & \multirow{2}{*}{\multicolumn{3}{|c|}{$\mathrm{R}^{2}=16.9 \%$}} & $-.07 *$ & $(.03)$ & {$[-.15 ;-.02]$} & & & & $3.15^{*}$ & (1.47) & {$[.27 ; 6.58]$} \\
\hline $\mathrm{R}^{2}$ & & & & $\mathrm{R}^{2}=17$ & $7.7 \%$ & & \multicolumn{3}{|c|}{$\mathrm{R}^{2}=9.8 \%$} & \multicolumn{3}{|c|}{$\mathrm{R}^{2}=12.5 \%$} \\
\hline
\end{tabular}

Boldface type indicates that the $95 \%$ posterior credibility interval (C.I.) does not include zero. S.D. $=$ Posterior standard deviation

$*=p<.05$ (one-tailed); $* *=p<.01$ (one-tailed)

${ }^{a}$ We conducted robustness checks to rule out alternative explanations. However, inclusion of either group-level CSB (as an additional motivation to exert CSB) or structural market elements (see section on Robustness of results) did not alter our initial findings. For reasons of parsimony, we decided not to report them here. More information about the robustness checks is available from the first author upon request

\section{Consequences of CSB}

With regard to CSB's consequences, the results show a negative effect of CSB on effort to sell new products $\left(\mathrm{CI}_{95 \%}=[-.33\right.$; $-.01])$. This supports H5a. Furthermore, new product selling effort was positively related to both performance measures, i.e., managerial overall performance evaluation $\left(\mathrm{Cl}_{95 \%}=[.05 ; .25]\right)$ and new product selling performance $\left(\mathrm{CI}_{95 \%}=[1.87 ; 9.77]\right)$. This provides support for $\mathrm{H} 5 \mathrm{~b}$ and $\mathrm{H} 5 \mathrm{c}$, respectively. Finally, CSB weakened the positive relationship between effort and manager's evaluations $\left(\mathrm{CI}_{95 \%}=[-.15 ;-.02]\right)$, providing support for H6a. In contrast, CSB strengthened the positive relationship between effort and new product selling performance $\left(\mathrm{Cl}_{95 \%}=[.27 ; 6.58]\right)$ in support of H6b. This provides evidence for the thought that although managers see CSB as an undesirable behavior, it may in fact benefit sales performance. Figure 3's panels A and B present a more detailed account of the interaction effects of effort and CSB, again for values of 1 standard deviation below and above the mean of the independent variable and the moderator.

To test whether effort, in its relationship with performance, both mediates and interacts with CSB, we calculated the index of moderated mediation for CSB (Hayes 2015). In our "independent variable as moderator" model, the indirect effect of CSB on SPO through EFF is the product of the effect of CSB from Eq. 2 and the conditional effect of EFF on SPO from Eq. 3 (see Preacher et al. 2007 for a detailed discussion). Formally:

$\omega=\alpha_{40}\left(\theta_{20}+\theta_{40} \operatorname{CSB}_{i j}\right)$,

which equals:

$\omega=\alpha_{40} \theta_{20}+\alpha_{40} \theta_{40} \mathrm{CSB}_{i j}$

with intercept $\alpha_{40} \theta_{20}$ and slope $\alpha_{40} \theta_{40} \mathrm{CSB}_{i j}$. In this model $\alpha_{40} \theta_{40} \mathrm{CSB}_{i j}$ is the index of moderated mediation. Using Bayesian estimation, we obtained $95 \%$ credible intervals. The moderated mediation indices for CSB on a manager's overall performance evaluation and new product selling performance are both significantly different from zero $\left(\mathrm{CI}_{95 \%}=[.01 ; .04]\right.$ and $[-1.92 ;-.05]$, respectively $)$. This supports the moderated mediation effect of CSB and demonstrates that the negative indirect effect of CSB on managerial overall performance evaluation increases with higher values of CSB, as the slope of the line (or the index of moderated mediation) is positive, while the negative indirect effect of CSB on new product selling performance decreases with 


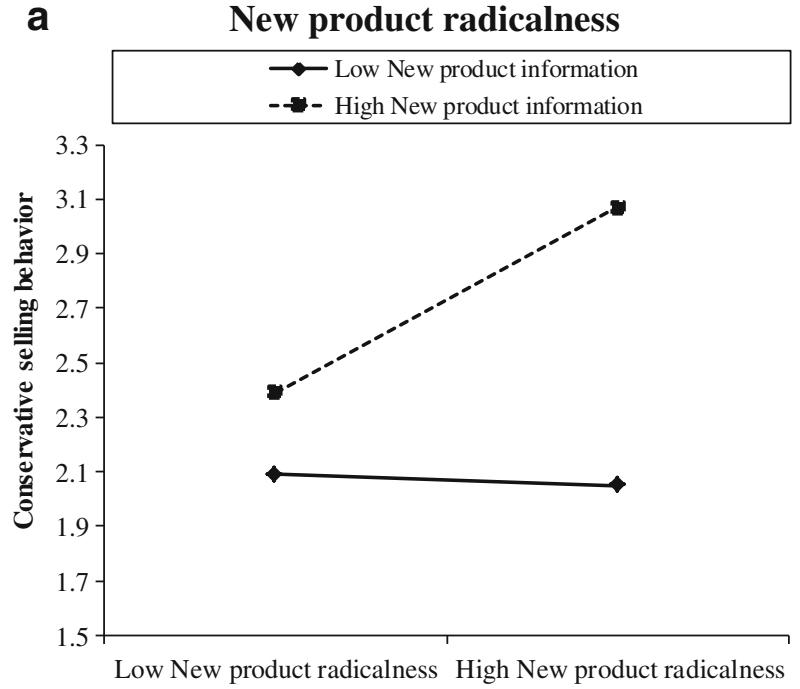

\section{b Managerial new product orientation}
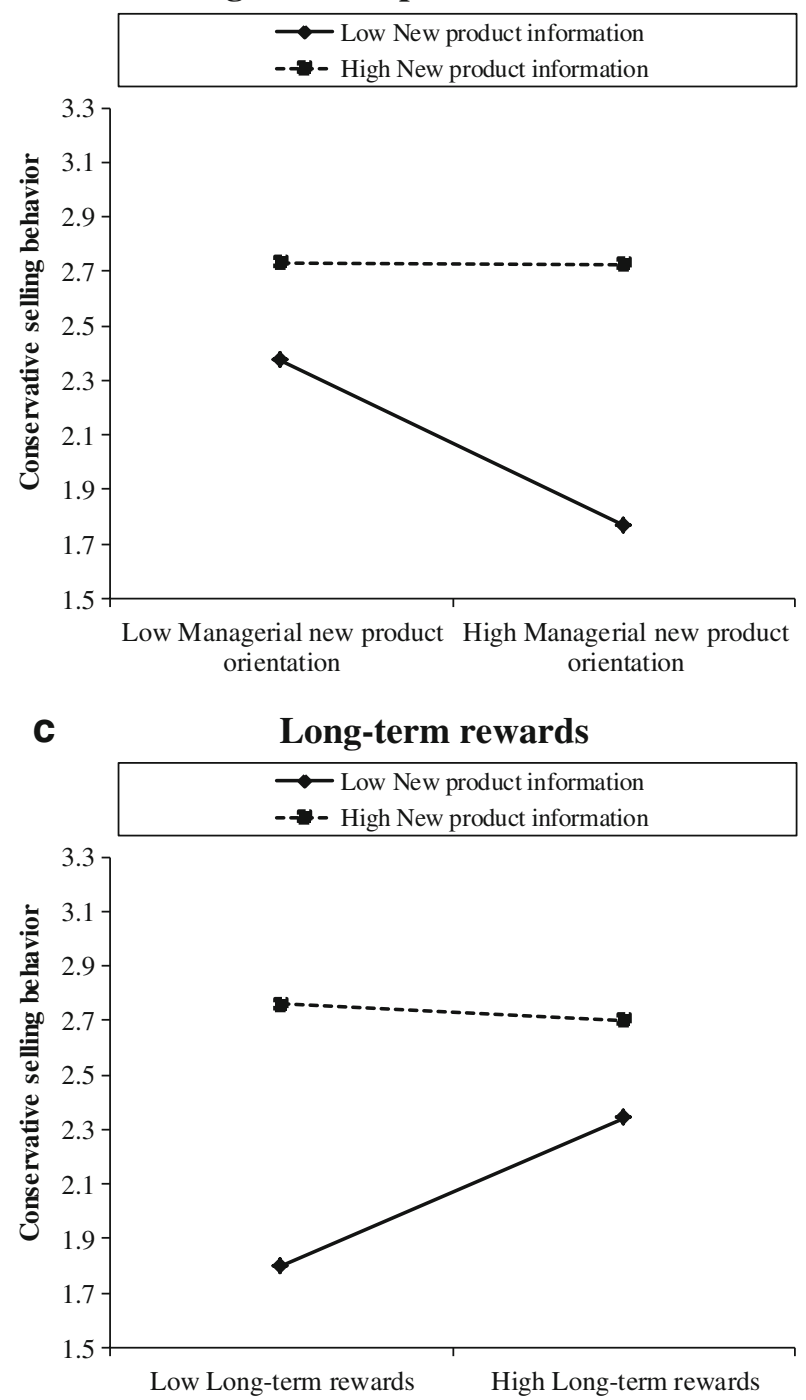

Fig. 2 Two-way interactions of antecedents on CSB. a New product radicalness. b Managerial new product orientation. c Long-term rewards a Managerial overall performance evaluation

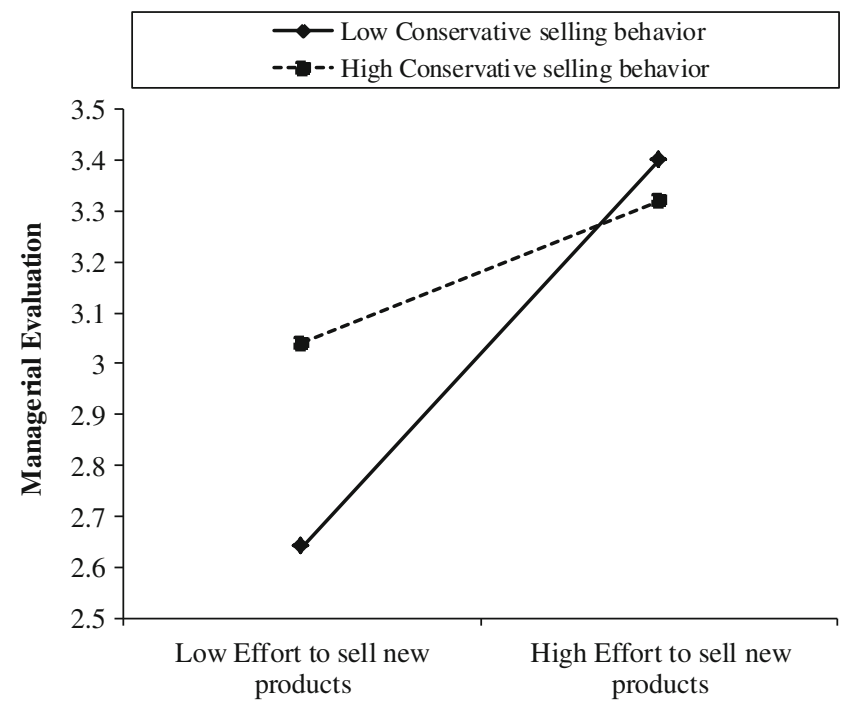

b $\%$ Sales volume obtained

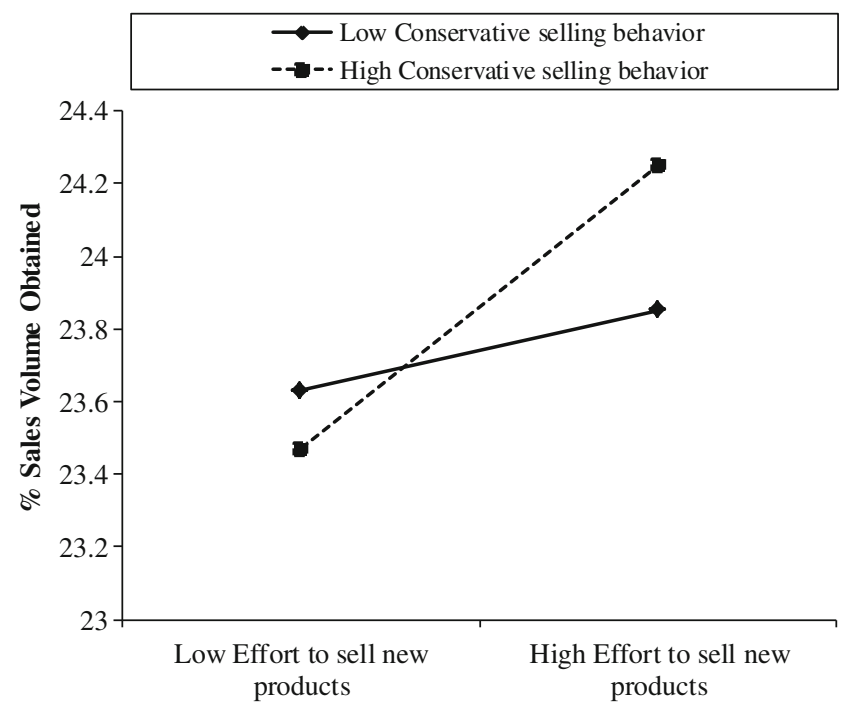

Fig. 3 Two-way Interactions of Consequences of CSB. a Managerial overall performance evaluation. b \% Sales volume obtained

higher values of CSB. In sum, the findings further corroborate our expectations.

Of our control variables, company tenure positively associated with $\mathrm{CSB}\left(\mathrm{CI}_{95 \%}=[.02 ; .32]\right)$. Probably, more tenured employees have gained more status and are reluctant to incur any damage by making risky choices. Alternatively, more tenured employees may be older and therefore more likely to resist change and be more conservative in their decision making. As expected, selfconfidence associated negatively with CSB $\left(\mathrm{CI}_{95 \%}=[-.49 ;-.08]\right)$ and positively with effort to sell new products $\left(\mathrm{CI}_{95 \%}=[.17 ; .59]\right)$. Next, customer relationship quality positively associated with effort to sell new products $\left(\mathrm{CI}_{95 \%}=[.07 ; .38]\right)$. This suggests that trusted relations make salespeople more willing to increase their 
effort allocated to that account. An alternative explanation could be that these accounts demand more from the salesperson (Mullins et al. 2014). Finally, in line with previous studies we find that past performance positively associates with managerial overall performance evaluations $\left(\mathrm{CI}_{95 \%}=[.04 ; .23]\right)$. All of these results are intuitive and thus offer face validity to our data and increase the confidence in our outcomes.

\section{Robustness of results}

Adequacy of sample To further demonstrate the suitability of our Sample 1 and hence the generalizability of our findings, we triangulated our outcomes with results of previous studies on new product selling. Specifically, we compiled a descriptive meta-analytic overview on the relationship between new product selling effort and performance and then contrasted past findings with our results. Table 5 shows that our results closely mirror and replicate the stream of related work. This provides additional evidence of the suitability of our data and the generalizability of our findings.

Market context and conditions Using perceived risk processing theory as the theoretical lens for understanding CSB, our conceptual model focuses on the role of risk perceptions of individual salespeople. However, it could be that CSB is more a function of the market context and conditions into which salespeople are selling. To rule out this alternative line of thinking and to further demonstrate the robustness of our findings we conducted some additional tests.

First, consistent with the company's targeting approach we dummy-coded four clusters of industries: (1) finance, (2) government \& education, (3) industry \& transport, and (4) services, retail, \& media. This particular coding scheme was motivated by leading classifications of industries such as the North American Industry Classification System (NAICS), Eurostat, and Statistics Netherlands' StatLine. Second, we collected secondary data for the industries defined at a more granular level (i.e., two-digit industry codes). Specifically, we collected for each industry: size (i.e., number of companies with more than 250 employees), production volume change (production index), and innovation expenditures (in millions of Euros). These data are considered as proxies for each industry's market potential, growth rate, and investments in new technology (e.g., our Sample 1 company’s ICT solutions) respectively. Third, we added the dummy-coded industries to our conceptual model as covariates for CSB, effort, and performance outcomes. Adding these dummies did not change our initial findings, and none of the dummy variables turned out to be significant. Finally, we replaced the dummies with the three market conditions per industry. Adding these factors did not alter the findings of our hypothesized model either.
These results support our rationale for adopting a perceptual view on salesperson behavior and corroborate the robustness of our findings.

\section{Discussion}

Many B2B salespeople display conservatism when confronted with new products in their portfolio, such that they maximize their efforts to sell existing products before engaging in efforts to sell the new product. This article provides an answer to the question of whether such conservative approaches to new product selling are a blessing in disguise. Although anecdotal evidence existed and patches of argumentation could be found in literature to argue that CSB could benefit rather than harm the sales of new products, conservative selling approaches have remained unstudied. In response, building on perceived risk processing theory, we established and tested a conceptual model of antecedents and consequences of CSB. We outline our findings and implications next.

\section{Theoretical implications}

Our work has several important theoretical implications. First, we add to existing work in new product selling by conceptualizing, operationalizing, and validating the concept of CSB. We conceptualize CSB as a sales domainspecific behavioral representation of risk aversion. The latter has been a central assumption in the sales domain and in new product selling in particular (Atuahene-Gima 1997). We show that CSB differs from related constructs such as new product selling effort.

Remarkably, we find that when salespeople first try to sell existing products before they engage in new product selling, their effort to sell new products more strongly translates into percentage of sales volume obtained with new products. Explanations for this effect can be found in how customers strive for consistent responses to sales requests (Cialdini and Guadagno 2004), creeping commitment in B2B sales cycles, and salespeople's potential to better communicate the new product's attractiveness through highlighting new features vis-à-vis old (or missing) features (Thompson et al. 2005). Previous literature has shown that adapting sales presentations to the nature of the sales situation benefits overall sales performance (Franke and Park 2006) but has remained silent on the specific alterations needed in new product selling. We show that the order of presenting the customer with new and existing products is a key factor in such adaptive strategies.

Second, we add to recent work on internal marketing of new products (e.g., Wieseke et al. 2008). In contrast to the 
Table 5 Descriptive meta-analytic triangulation of previous new product selling research

\begin{tabular}{|c|c|c|c|c|c|}
\hline Study & Effort measure & Performance measure & $\begin{array}{l}\text { Effect size } \\
\text { (Fisher's Zr) }\end{array}$ & Sample size & Industry \\
\hline $\begin{array}{l}\text { Atuahene-Gima and } \\
\text { Micheal (1998) }\end{array}$ & Self-reported & Self-reported & .2895 & 118 & $\begin{array}{l}\text { Electrical; electronic and information } \\
\text { technology, industrial equipment } \\
\text { and systems, instruments, fabricated } \\
\text { metals and motor parts, chemical and } \\
\text { pharmaceuticals and building products }\end{array}$ \\
\hline $\begin{array}{l}\text { Hultink and } \\
\text { Atuahene-Gima (2000) }\end{array}$ & Self-reported & Self-reported & .0902 & 97 & Technology firms. \\
\hline $\begin{array}{l}\text { Atuahene-Gima } \\
\quad \& \text { Li (2002) }\end{array}$ & $\begin{array}{l}\text { Hours worked } \\
\text { per week (HR) }\end{array}$ & Self-reported & $\begin{array}{l}.1409 \\
(\text { sample 1) } \\
.1206 \\
\text { (sample 2) }\end{array}$ & $\begin{array}{l}157 \\
190\end{array}$ & $\begin{array}{l}\text { Electronics, information technology, } \\
\text { software development, biotechnology, } \\
\text { and other high-technology sectors }\end{array}$ \\
\hline Fu et al. (2009) & Self-reported & Actual number of units sold & .3316 & 143 & Tooling industry \\
\hline $\begin{array}{l}\text { Ahearne et al. } \\
\text { (2010) }\end{array}$ & $\begin{array}{l}\text { Total number } \\
\text { of sales calls made }\end{array}$ & Percentage of sales quota & .1996 & 226 & Pharmaceutical industry \\
\hline Aggregated effect size: & & & .1954 & 931 & \\
\hline \multicolumn{6}{|l|}{ The present study } \\
\hline Sample 1 & Self-reported & Percentage of sales volume & .2027 & 172 & $\begin{array}{l}\text { Information and communication } \\
\text { technology industry }\end{array}$ \\
\hline
\end{tabular}

traditional view that internal marketing efforts motivate salespeople to sell new products (Atuahene-Gima 1997; Johnson and Sohi 2016), we show that this relationship is not straightforward. Salespeople perceive different risk dimensions surrounding the sale of new products. Providing new product information changes the relative weight of the dimensions in salespeople's decisions to act conservatively. More specifically, product radicalness (performance risk) becomes a more important driver of CSB, while managerial orientations (social risk) and long-term rewards (financial risk) become less important. Especially the latter finding is interesting because without information, long-term rewards tend to increase rather than decrease CSB. Long-term rewards may focus salespeople on selling existing products, while short-term rewards provoke risk taking.

Finally, we add to work on (sales) personnel evaluation. Previous studies have showed that sales managers are sensitive to subordinates exerting high levels of effort (Harris et al. 2014). Early work also indicates that sales managers often fail to account for the task difficulty facing their employees (Mowen et al. 1985) and that more tactical elements such as planning ability, judgment, and time management are of lesser importance in performance appraisals (Hawes et al. 1995; Pettijohn et al. 2001). Our findings align with and add more detail to these insights. We show that managers are less appreciative of effort to sell new products when this effort follows a period of salesperson conservatism. Although this practice does not honor the associated sales performance, it does suggest that sales managers take into account a longer time-frame in their appraisals and do not suffer from "recency bias" (Brown and Heywood 2005) such that recent events have more influence on appraisals than less recent events. Our findings suggest that sales managers can oversee the entire length of the sales cycle and that they factor in the timing of their subordinates' effort.

\section{Managerial implications}

Our work offers important insights for managers. First, we urge sales managers to get a better understanding of the conservative behavior of their salespeople. Many managers worry that salespeople maximize their selling efforts for existing products before engaging in efforts to sell the new product and that this practice makes them less effective in selling new products. However, a conservative selling approach may help salespeople to provide a better pitch to customers who are then more likely to agree to risky value propositions. This is especially likely in B2B settings, where sales cycles extend over time and adopting a new product means that the customer faces significant changes to its workflows. 
Second, managers' better understanding of conservatism should go hand-in-hand with rethinking salespeople's performance appraisals. Many managers use criteria such as product knowledge, attitude, effort, initiative, and aggressiveness in their performance evaluations of salespeople. Specifically, they correlate observed lack of effort to sell new products to a salesperson's attitude and work motivation, consequently attribute negative traits to him or her, and adjust their evaluation of this person's work performance downward. This may be unfair in markets where conservative selling behavior is a smart selling strategy.

Third, managers have routinely tried to control the levels of conservatism in their salesforce by using incentive systems, being an advocate of selling new products, and ramping up internal marketing on new products toward their employees. Rather than doing all at once, we urge managers to consider the interrelationships between these control mechanisms (see Fig. 2). Our results point to three possible control scenarios: (1) Managers responsible for launching radically new products can enhance CSB by setting up intensive internal marketing efforts via the provision of new product information. In this scenario, managers are advised to save their scarce resources of personally motivating sales staff and installing long-term rewards systems because providing new product information makes these mechanisms less suitable to regulate CSB. (2) Managers responsible for launching less radically new products can enhance CSB by rewarding the obtainment of objectives and goals in a time frame for longer than one year. Importantly, this strategy only works when providing no or very limited new product information to salespeople. (3) Managers who are looking to decrease $\mathrm{CSB}$ - perhaps because of a more transactional selling context or because CSB does not fit the organization's image-are most successful when they do not provide new product information and set short-term (rather than long-term) goals. This runs counter to present-day management practices and explains why companies are often unsuccessful in managing CSB. Personally motivating subordinates to sell new products without providing new product information is likely to further decrease CSB.

Finally, there are many trade-offs that sales employees and their managers have to make because new products are added to a portfolio of existing products. B2B managers could think about allocating a specific part of their salesforce to sell new products and the remaining part to sell existing products. An alternative to this solution is to hire new salespeople to sell new products. A problem here, though, is that a lower quality of customer relationships limits the knowledge exchange between salesperson and customer. This may hamper the transfer of customer feedback into the company's development department and thus block bug fixing and product quality improvement.

\section{Limitations and future research}

Although we believe our study has clear merits, there are some limitations too. Some of them provide fruitful avenues for future research. First, we relied on salesperson perceptions of new product radicalness, managerial new product orientation, and long-term rewards. Although this fits with our perceived risk processing framework, recent studies indicate that employee perceptions may be different from customer-side perceptions or manager perceptions and relate differently to performance outcomes (e.g., Mullins et al. 2014). Including customers as a data source would provide further evidence for the validity of our findings, but collecting a sample of representative respondents is hard in B2B settings.

In addition, we demonstrated the robustness of our findings through triangulation with previous results and controlling for market context and conditions. We hold that our sample profile is typical for firms with field salesforces and frequent introductions of new products in many industries, such as machinery, chemicals, plastic materials, equipment and supplies, and pharmaceuticals. Assuming that with increasing frequency of new product introductions salespeople get more used to selling new and unfamiliar products, we expect that any CSB-related effects also hold for (or may even be stronger in) industries with a lower frequency of new product introductions. However, in industries where competition offers similar products, salespeople have limited time to convince customers, or where fad products are concerned, CSB may have different effects. Future research should hence substantiate the effects across industries to see in which situations CSB is most beneficial.

Acknowledgements The authors thank Ko de Ruyter, Frank Germann, Bart Larivière, Maik Hammerschmidt, Ed Nijssen, Ad de Jong, and Néomie Raassens for their constructive comments on previous versions of this manuscript. 


\section{Appendix A}

Table 6 Psychometric properties of conservative selling behavior scale

Construct / item

Sample $1 \quad$ Sample 2

$(\mathrm{n}=172)$

\begin{tabular}{rrrrrrrr}
\hline FL & AVE & CR & CA & FL & AVE & CR & CA \\
\hline & $\mathbf{7 3}$ & $\mathbf{8 9}$ & $\mathbf{. 8 3}$ & & $\mathbf{. 6 4}$ & $\mathbf{. 8 4}$ & $\mathbf{. 7 3}$
\end{tabular}

Conservative selling behavior (new scale)

Over the past 12 months,

1 I always tried to maximize my selling efforts for existing products before considering the new products.

2 I preferred selling existing products above selling new products.

3 I behaved cautiously in selling new products.

Effort to sell new products (Adapted from Sujan et al. 1994 and

Hultink and Atuahene-Gima 2000)

When I engage in the activity of new product selling, I...

1 always take the initiative.

2 do not give up easily when encountering a customer to whom it is difficult to sell new products.

3 always anticipate and act upon potential problems.

4 am constantly on the lookout to identify opportunities.

5 actively scan emerging needs.

Adaptive selling (Fang et al. 2004; Román and Iacobucci 2010)

1 I use different sales strategies with different customers.

2 I vary my sales style from situation to situation.

3 I change my sales approach from one customer to another.

4 I am very flexible in the selling approach I use.

5 I tend to use a wide variety of selling approaches with different customers.

Cross selling (Adapted from Schmitz 2013)

Over the past 12 months,

1 I tried to cover my customers' needs for additional products on a broad basis.

2 I made my customers obtain additional products they required.

3 I ensured that my customers purchased many additional products our company offers.

4 I exploited my customers' potential with regard to additional products extensively.

New product commitment (Hultink and Atuahene-Gima 2000)

1 I feel emotionally attached to the success of the new products.

2 Achieving objectives for the new products has a great deal of personal meaning to me.

3 I enjoy discussing the new products with other salespeople.

4 I feel a strong sense of duty to ensure the success of the new products.

5 I would be willing to make further investment of my time and energy to support these new products.

$\begin{array}{llllllllll}.85 & & & & & .82 & & & \\ & & & & & & & \\ .89 & & & & .86 & & & \\ .81 & & & & .71 & & & \\ & & & .75 & .94 & .93 & & .61 & .89 & .85\end{array}$

$.90 \quad .82$

$.86 \quad .82$

$.83 \quad .79$

$.87 \quad .79$

$83 \quad .61$

$\begin{array}{rrrrr}. & - & - & - & \\ - & & & & .80\end{array}$

$65 \quad 90 \quad 90$

.80

.80

.82

.80

.82

$\begin{array}{lll}.51 & .75 & .67\end{array}$

.54

.77

.65

.70

$\begin{array}{lll}.65 & .88 & .86\end{array}$

.86

.82

.71

.82

.83

All loadings are significant at $p<.01$. Fit indice (Sample 1): ppp $=.862$. Fit indice (Sample 2): ppp $=.590$. FL $=$ factor loading, $\mathrm{CR}=$ composite reliability, and $\mathrm{CA}=$ Cronbach's alpha. Highest correlation between constructs in Sample $2 \rho=.58$ (Effort to sell new products-New product commitment)

Boldface type indicates latent constructs

We further evaluated the validity of our CSB scale in Sample 1 using a second dataset (Sample 2) obtained from a commercially available panel of B2B salespeople. We included our three CSB items and the scales of related concepts in a survey that was sent to 341 salespeople. We received 191 usable responses, for a response rate of $56.0 \%$. On average, these salespeople had 18.03 years of work experience in sales jobs and 9.50 years with their company. The Sample 2 CFA showed a good fit of the measurement model to the retest data (i.e., a ppp-value of 
$.590)$, and each indicator loaded significantly $(p<.01)$ on the appropriate factor. As in Sample 1, the CSB scale displayed desirable psychometric properties. We also found CSB to satisfy the criteria for discriminant validity when including the related concepts from literature. Sample 2 thus helped to empirically distinguish CSB from the concepts we presented in Table 1. Table 6 presents our empirical results.

Open Access This article is distributed under the terms of the Creative Commons Attribution 4.0 International License (http:// creativecommons.org/licenses/by/4.0/), which permits unrestricted use, distribution, and reproduction in any medium, provided you give appropriate credit to the original author(s) and the source, provide a link to the Creative Commons license, and indicate if changes were made.

\section{References}

Ahearne, M., Rapp, A., Hughes, D. E., \& Jindal, R. (2010). Managing sales force product perceptions and control systems in the success of new product introductions. Journal of Marketing Research, 47(4), 764-776.

Ajzen, I. (1991). The theory of planned behavior. Organizational Behavior and Human Decision Processes, 50(2), 179-211.

Allcott, H., \& Sweeney, R. L. (2016). The role of sales agents in information disclosure: evidence from a field experiment. Management Science, Forthcoming, 1-19. doi:10.1287/mnsc.2015.2327

Anderson, E., \& Robertson, T. S. (1995). Inducing multiline salespeople to adopt house brands. Journal of Marketing, 59(2), 16-31.

Anderson, J. C., Narus, J. A., \& Van Rossum, W. (2006). Customer value propositions in business markets. Harvard Business Review, 84(3), 1-11.

Angelos, J., Tayob, T., \& Berumen, B. (2017). Powering profitable growth. Accenture, 1-24. (forthcoming)

Atuahene-Gima, K. (1997). Adoption of new products by the sales force: the construct, research propositions, and managerial implications. Journal of Product Innovation Management, 14(6), 498-514.

Atuahene-Gima, K., \& Li, H. (2002). When does trust matter? Antecedents and contingent effects of supervisee trust on performance in selling new products in China and the United States. Journal of Marketing, 66(3), 61-81.

Atuahene-Gima, K., \& Micheal, K. (1998). A contingency analysis of the impact of salesperson's effort on satisfaction and performance in selling new products. European Journal of Marketing, 32(9/10), 904-921.

Brown, M., \& Heywood, J. S. (2005). Performance appraisal systems: determinants and change. British Journal of Industrial Relations, 43(4), 659-679.

Cialdini, R. B., \& Guadagno, R. E. (2004). Sequential request compliance tactics. Persuasion, compliance-gaining, and social influence. Boston: Allyn \& Bacon.

Cohen, J., Cohen, P., West, S. G., \& Aiken, L. S. (2003). Applied multiple correlation/regression analysis for the behavioral sciences. Mahwah: Lawrence Erlbaum Associates.

Collins, A. M., \& Loftus, E. F. (1975). A spreading-activation theory of semantic processing. Psychological Review, 82(6), 407-428.

Conchar, M. P., Zinkhan, G. M., Peters, C., \& Olavarrieta, S. (2004). An integrated framework for the conceptualization of consumers' perceived-risk processing. Journal of the Academy of Marketing Science, 32(4), 418-436.

Corporate Visions. (2015). New corporate visions survey finds B2B companies agree sales conversations have biggest impact on closed deals, but still primarily invest in sales processes instead. Corporate Visions. http://corporatevisions.com. Accessed 20 Dec 2016.
DeCarlo, T. E., \& Lam, S. K. (2016). Identifying effective hunters and farmers in the salesforce: a dispositional-situational framework. Journal of the Academy of Marketing Science, 44(4), 415-439.

Detert, J. R., \& Burris, E. R. (2007). Leadership behavior and employee voice: is the door really open ? Academy of Management Journal, 50(4), 869-884.

Dowling, G. R., \& Staelin, R. (1994). A model of perceived risk and intended risk-handling activity. Journal of Consumer Research, 21(1), 119-134.

Erdem, T., \& Swait, J. (1998). Brand equity as a signaling phenomenon. Journal of Consumer Psychology, 7(2), 131-157.

Fang, E., Palmatier, R. W., \& Evans, K. R. (2004). Goal-setting paradoxes? Trade-offs between working hard and working smart: the United States versus China. Journal of the Academy of Marketing Science, 32(2), 188-202.

Franke, G. R., \& Park, J.-E. (2006). Salesperson adaptive selling behavior and customer orientation: a meta-analysis. Journal of Marketing Research, 43(4), 693-702.

Fu, F. Q., Jones, E., \& Bolander, W. (2008). Product innovativeness, customer newness, and new product performance: a time-lagged examination of the impact of salesperson selling intentions on new product performance. Journal of Personal Selling \& Sales Management, 28(4), 351-364.

Fu, F. Q., Richards, K. A., \& Jones, E. (2009). The motivation hub: effects of goal setting and self-efficacy on effort and new product sales. Journal of Personal Selling \& Sales Management, 29(3), 277-292.

Fu, F. Q., Richards, K. A., Hughes, D. E., \& Jones, E. (2010). Motivating salespeople to sell new products: the relative influence of attitudes, subjective norms, and self-efficacy. Journal of Marketing, 74(6), 61-76.

Harris, E. G., Brown, T. J., Mowen, J. C., \& Artis, A. (2014). Exploring the role of productivity propensity in frontline employee performance: its relationship with customer orientation and important outcomes. Psychology \& Marketing, 31(3), 171-183.

Hawes, J. M., Jackson Jr., D. W., Schlacter, J. L., \& Wolfe, W. G. (1995). Selling and sales Management in Action Examining the bases utilized for evaluating Salespeoples' performance. Journal of Personal Selling \& Sales Management, 15(4), 57-65.

Hayes, A. F. (2015). An index and test of linear moderated mediation. Multivariate Behavioral Research, 50(1), 1-22.

Hoch, S. J. (2002). Product experience is seductive. Journal of Consumer Research, 29(3), 448-454.

Hughes, D. E. (2013). This ad's for you: the indirect effect of advertising perceptions on salesperson effort and performance. Journal of the Academy of Marketing Science, 41(1), 1-18.

Hultink, E. J., \& Atuahene-Gima, K. (2000). The effect of sales force adoption on new product selling performance. Journal of Product Innovation Management, 17(6), 435-450.

Jacoby, J., \& Kaplan, L. B. (1972). The components of perceived risk. Proceedings of the Third Annual Conference, Ann Arbour, MI, Association for Consumer Research.

Jasmand, C., Blazevic, V., \& De Ruyter, K. (2012). Generating sales while providing service: a study of customer service representatives' ambidextrous behavior. Journal of Marketing, 76(1), 20-37.

Johnson, J. S., \& Sohi, R. S. (2016). Getting business-to-business salespeople to implement strategies associated with introducing new products and services. Industrial Marketing Management, Forthcoming, 1-13. doi:10.1016/j.indmarman.2016.08.006.

Jost, J. T., Glaser, J., Kruglanski, A. W., \& Sulloway, F. J. (2003). Political conservatism as motivated social cognition. Psychological Bulletin, 129(3), 339-375.

Judd, C. M., \& Kenny, D. A. (1981). Process analysis estimating mediation in treatment evaluations. Evaluation Review, 5(5), 602-619.

Kahneman, D., \& Tversky, A. (1979). Prospect theory: an analysis of decision under risk. Econometrica: Journal of the Econometric Society, 47(2), 263-291. 
Kamakura, W. A. (2008). Cross-selling: offering the right product to the right customer at the right time. Journal of Relationship Marketing, $6(3-4), 41-58$.

Kauppila, O.-P., Rajala, R., \& Jyrämä, A. (2010). Antecedents of salespeople's reluctance to sell radically new products. Industrial Marketing Management, 39(2), 308-316.

Kuester, S., Homburg, C., \& Hildesheim, A. (2016). The catbird seat of the sales force: how sales force integration leads to new product success. International Journal of Research in Marketing, Forthcoming, 1-18. doi:10.1016/j.ijresmar.2016.08.008.

Labrecque, J. S., Wood, W., Neal, D. T., \& Harrington, N. (2016). Habit slips: when consumers unintentionally resist new products. Journal of the Academy of Marketing Science, Forthcoming, 1-15. doi:10.1007/s11747-016-0482-9.

Langerak, F., Hultink, E. J., \& Griffin, A. (2008). Exploring mediating and moderating influences on the links among cycle time, proficiency in entry timing, and new product profitability. Journal of Product Innovation Management, 25(4), 370-385.

Low, G. S., \& Mohr, J. J. (2001). Factors affecting the use of information in the evaluation of marketing communications productivity. Journal of the Academy of Marketing Science, 29(1), 70-88.

Mandel, N. (2003). Shifting selves and decision making: the effects of self-construal priming on consumer risk-taking. Journal of Consumer Research, 30(1), 30-40.

Micheal, K., Rochford, L., \& Wotruba, T. R. (2003). How new product introductions affect sales management strategy: the impact of type of "newness" of the new product. Journal of Product Innovation Management, 20(4), 270-283.

Mitchell, V. W. (1999). Consumer perceived risk: conceptualisations and models. European Journal of Marketing, 33(1/2), 163-195.

Moore, G. A. (2006). To succeed in the long-term, focus on the middleterm. Harvard Business Review, 85(7-8), 84-90.

Mowen, J. C., Keith, J. E., Brown, S. W., \& Jackson Jr., D. W. (1985). Utilizing effort and task difficulty information in evaluating salespeople. Journal of Marketing Research, 22(2), 185-191.

Mullins, J. W., Forlani, D., \& Walker, O. C. (1999). Effects of organizational and decision-maker factors on new product risk taking. Journal of Product Innovation Management, 16(3), 282-294.

Mullins, R. R., Ahearne, M., Lam, S. K., Hall, Z. R., \& Boichuk, J. P. (2014). Know your customer: how salesperson perceptions of customer relationship quality form and influence account profitability. Journal of Marketing, 78(6), 38-58.

Muthén, B. O., \& Asparouhov, T. (2012). Bayesian structural equation modeling: a more flexible representation of substantive theory. Psychological Methods, 17(3), 313.

Muthén, L. K., \& Muthén, B. O. (2012). Mplus (7th ed.). Los Angeles: Muthén \& Muthén.

Palmatier, R. W. (2008). Interfirm relational drivers of customer value. Journal of Marketing, 72(4), 76-89.

Pettijohn, L. S., Parker, R. S., Pettijohn, C. E., \& Kent, J. L. (2001). Performance appraisals: usage, criteria and observations. Journal of Management Development, 20(9), 754-771.

Podsakoff, P. M., \& Mackenzie, S. B. (1994). Organizational citizenship behaviors and sales unit effectiveness. Journal of Marketing Research, 351-363.

Preacher, K. J., Rucker, D. D., \& Hayes, A. F. (2007). Addressing moderated mediation hypotheses: theory, methods, and prescriptions. Multivariate Behavioral Research, 42(1), 185-227.

Preacher, K. J., Zyphur, M. J., \& Zhang, Z. (2010). A general multilevel SEM framework for assessing multilevel mediation. Psychological Methods, 15(3), 209-233.

Rackham, N. (1998). From experience: why bad things happen to good new products. Journal of Product Innovation Management, 15(3), 201-207.

Rapp, A., Ahearne, M., Mathieu, J., \& Schillewaert, N. (2006). The impact of knowledge and empowerment on working smart and working hard: the moderating role of experience. International Journal of Research in Marketing, 23(3), 279-293.

Román, S., \& Iacobucci, D. (2010). Antecedents and consequences of adaptive selling confidence and behavior: a dyadic analysis of salespeople and their customers. Journal of the Academy of Marketing Science, 38(3), 363-382.

Scheufele, D. A., \& Tewksbury, D. (2007). Framing, agenda setting, and priming: the evolution of three media effects models. Journal of Communication, 57(1), 9-20.

Schmitz, C. (2013). Group influences of selling teams on industrial salespeople's cross-selling behavior. Journal of the Academy of Marketing Science, 41(1), 55-72.

Schmitz, C., Lee, Y.-C., \& Lilien, G. L. (2014). Cross-selling performance in complex selling contexts: an examination of supervisory-and compensation-based controls. Journal of Marketing, 78(3), 1-19.

Schneider, B., Hanges, P. J., Smith, D. B., \& Salvaggio, A. N. (2003). Which comes first: employee attitudes or organizational financial and market performance ? Journal of Applied Psychology, 88(5), $836-851$

Schöttner, A. (2016). Optimal sales force compensation in dynamic settings: commissions vs. Bonuses. Management Science, Forthcoming, 1-16. doi:10.1287/mnsc.2015.2397

Sitkin, S. B., \& Pablo, A. L. (1992). Reconceptualizing the determinants of risk behavior. Academy of Management Review, 17(1), 9-38.

Song, X. M., \& Montoya-Weiss, M. M. (1998). Critical development activities for really new versus incremental products. Journal of Product Innovation Management, 15(2), 124-135.

Stein, D. (2011). Sales training: the 120-days curse. ES Research Group, Inc. www.profnetconnect.com/davestein/blog. Accessed 20 Dec 2016.

Sujan, H., Weitz, B. A., \& Kumar, N. (1994). Learning orientation, working smart, and effective selling. Journal of Marketing, 58(3), 39-52.

Thompson, D. V., Hamilton, R. W., \& Rust, R. T. (2005). Feature fatigue: when product capabilities become too much of a good thing. Journal of Marketing Research, 42(4), 431-442.

Van der Borgh, M., \& Schepers, J. J. (2014). Do retailers really profit from ambidextrous managers? The impact of frontline mechanisms on new and existing product selling performance. Journal of Product Innovation Management, 31(4), 710-727.

Van der Borgh, M., De Jong, A., \& Nijssen, E. J. (2015). Alternative mechanisms guiding salespersons' ambidextrous product selling. British Journal of Management, Forthcoming, 1-23. doi:10.1111 /1467-8551.12148.

Wang, H. (2015). Risk aversion and CEO selection. In European Financial Management Association, 2015 Annual Meetings, June 24-27, 2015, Amsterdam, NETHERLANDS Accessed at: http://www.efmaefm. org/0 EFMAMEETIN G S / EFM A \% 20 ANNUAL \% 20 MEETINGS/2015-Amsterdam/papers/EFMA2015_0535_fullpaper. pdf.Accessed 24 July 2016.

Watts, R. L. (2003). Conservatism in accounting part I: explanations and implications. Accounting Horizons, 17(3), 207-221.

Wei, Y. S., \& Atuahene-Gima, K. (2009). The moderating role of reward systems in the relationship between market orientation and new product performance in China. International Journal of Research in Marketing, 26(2), 89-96.

Wieseke, J., Homburg, C., \& Lee, N. (2008). Understanding the adoption of new brands through salespeople: a multilevel framework. Journal of the Academy of Marketing Science, 36(2), 278-291.

Wilson, G. (2013). The psychology of conservatism (Routledge revivals). New York: Routledge.

Wiseman, R. M., \& Gomez-Mejia, L. R. (1998). A behavioral agency model of managerial risk taking. Academy of Management Review, 23(1), 133-153.

Zhang, J., Wedel, M., \& Pieters, R. (2009). Sales effects of attention to feature advertisements: a Bayesian mediation analysis. Journal of Marketing Research, 46(5), 669-681. 